\title{
RELATION OF THE WISSAHICKON MICA GNEISS TO THE SHENAN- DOAH LIMESTONE AND OCTORARO SCHIST OF THE DOE RUN AND AVONDALE REGION, CHESTER COUNTY, PENNSYLVANIA.
}

\author{
By Eleanora F. Bliss and Anna I. Jonas.
}

AREA DISCUSSED.

The region discussed in this paper lies in Chester County, Pa., and is included in the eastern half of the Coatesville quadrangle. (See fig. 3.) It is within the belt of crystal- stone.

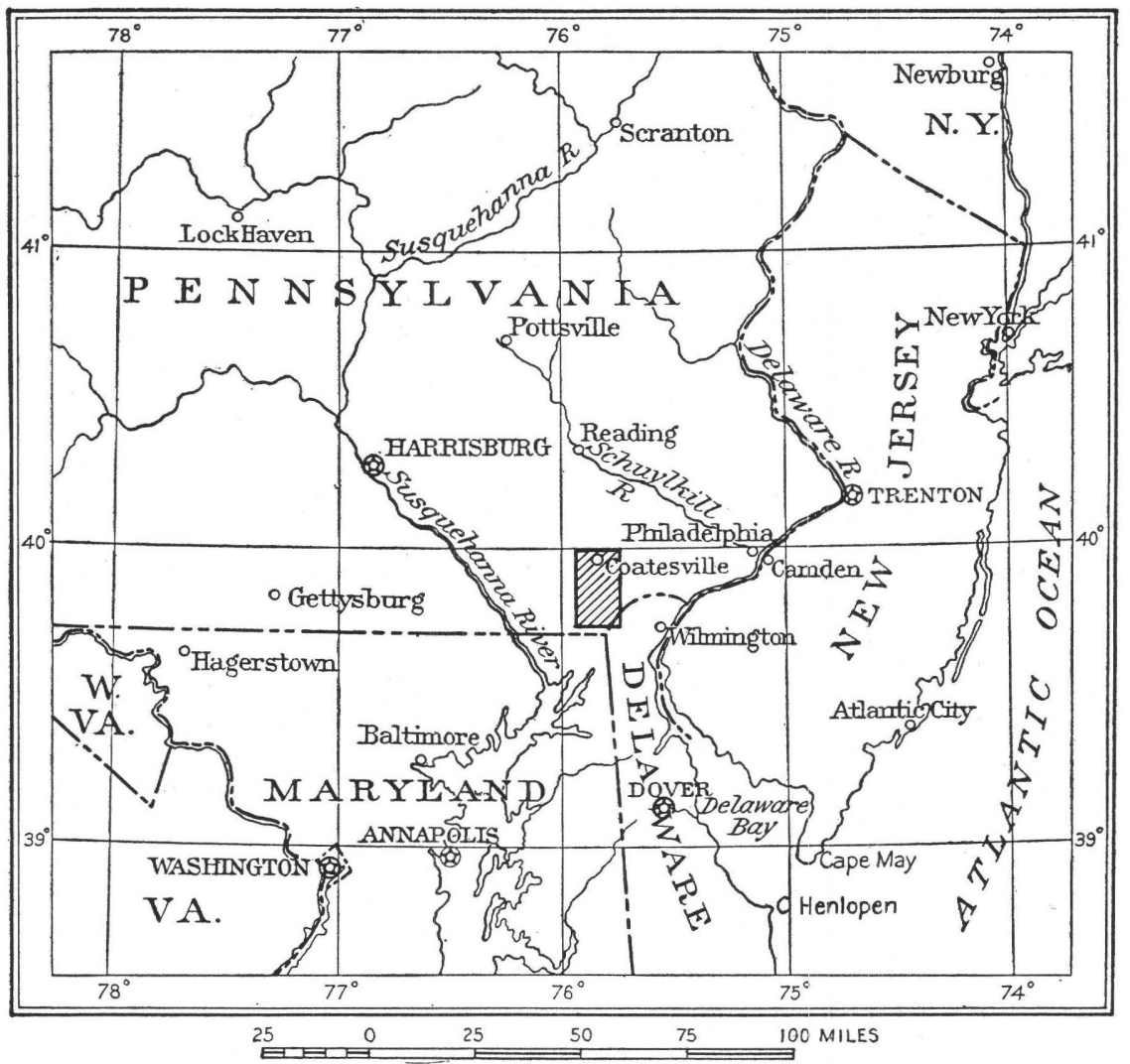

FIGURE 3.-Index map showing location of Doe Run and A vondale region, Chester County, Pa.

line schists and gneisses of the Piedmont Plateau. The northern half of the area, which will be called the Doe Run region, from the village of that name (see fig. 4, p. 15), has been surveyed by Eleanora F. Bliss in connection with the problem of the relation of the Wissahickon mica gneiss to the Octoraro schist. The southern half, the Avondale region (see fig. 5, p. 17), has been studied by Anna I. Jonas in order to determine the relation of the Wissahickon mica gneiss to the Shenandoah lime- 


\section{DESCRIPTIVE GEOLOGY.}

GENERAL RELATIONS.

All the rocks of this region have a like geologic history. The formations consist of metamorphic rocks, ranging in age from pre-Cambrian to Ordovician, and all of them are cut by fresh diabase dikes of the Triassic period. The high degree of metamorphism shown by the rocks of the region is characteristic of the formations of the southeastern part of the Piedmont Plateau as contrasted with those of the northwestern part, where dynamic action was less effective than in the southeast.

The succession of formations in the Coatesville quadrangle is as follows:

\author{
Metamorphic rocks: \\ Ordovician: Octoraro schist \\ Cambrian and Ordovician: Shenandoah limestone. \\ Cambrian: Chickies formation. \\ Pre-Cambrian: \\ Wissahickon mica gneiss. \\ Baltimore gneiss. \\ Igneous rocks: \\ Triassic: Diabase. \\ Pre-Silurian or younger: \\ Pegmatite. \\ Serpentine. \\ Early Cambrian or older: Metagabbro.
}

The Baltimore gneiss is a part of the preCambrian floor upon which the Paleozoic sediments were laid down. The Lower Cambrian represents coarse arenaceous sediments that were irregularly deposited on this floor. After the accumulation of these deposits the calcareous materials of the Cambrian and Ordovician periods were laid down and subsequently covered by clays of Ordovician age. These sediments have been altered in character, structure, and extent by compression, folding, uplift, and erosion. During Triassic time they were partly submerged, and gravel, sand, and clay were spread over the old eroded surface; these materials, in turn, have suffered partial removal by erosion, which cut through the Paleozoic rocks to the pre-Cambrian gneiss of the original floor.

The accompanying table shows the correlation of these formations with the rocks of New England, eastern New York, Maryland, Vir- ginia, and the southern Appalachian region. The distribution of these formations in the Doe Run and Avondale region is shown on Plate I.

It may be of interest to note the work of earlier investigators in the Philadelphia region. Conclusions on these formations published by the First and Second geological surveys of Pennsylvania are somewhat similar to each other.

H. D. Rogers, ${ }^{1}$ of the First Geological Survey, included all the gneisses (the Baltimore gneiss, the Wissahickon mica gneiss, and the granite, gabbro, and hornblende gneisses) in the older crystalline gneissic strata, which he grouped in three belts exposed in section on Schuylkill River from Grays Ferry, in Philadelphia, northward to Spring Mill. The first and second gneiss belts include the Wissahickon mica gneiss and an intrusive granite gneiss; the third belt represents the Baltimore gneiss. $\mathrm{He}$ called the Chickies formation "Primal white sandstone," which he made equivalent to the Potsdam or Upper Cambrian of New York; the Shenandoah limestone he called "Auroral magnesian limestone," which he correlated with the Chazy and Black River limestones of New York; the Octoraro schist he called "Primal upper slate" and placed over the "Primal sandstone."

C. E. Hall, ${ }^{2}$ of the Second Geological Survey, substituted the terms "Eozoic," "Azoic gneiss," and "Laurentian syenite" for the third belt and separated the first and second belts, beginning at the base, into "Philadelphia schists and gneisses" and "Chestnut Hill garnetiferous schists." The quartzite he called "Potsdam, formation No. 1"; the Shenandoah limestone, "formation No. 2," described as representing the "Calciferous and Trenton groups"; the Octoraro schist is his "formation No. 3," described as representing the "Hudson River group." The Octoraro schist is described by T. D. Rand ${ }^{3}$ under the term "hydro-mica schist."

1 Pennsylvania First Geol. Survey Rept., vol. 1, pp. 66-82, 122-183, 1858.

2 Pennsylvania Second Geol, Survey Rept., C6, pp. 1-47, 1881.

${ }^{3}$ Rand, T. D., Notes on the geology of Radnor Township, in Delaware County, Pa., and of the townships adjacent: Pennsylvania Geol. Survey Ann. Rept., 1886, pt. 4, p. 1580, 1887. 


\begin{tabular}{|c|c|c|c|c|c|c|c|c|c|c|c|c|c|c|}
\hline \multirow{3}{*}{ Geologic age. } & \multicolumn{4}{|c|}{ Southern Appalachian region. } & \multirow{3}{*}{$\begin{array}{l}\text { Harpers Ferry region: } \\
\text { Keiti } \\
\text { folio). Harpers } \\
\text { forry }\end{array}$} & \multirow{3}{*}{ 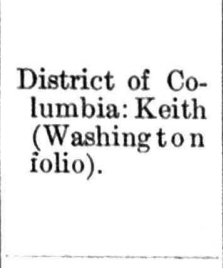 } & \multirow{3}{*}{ 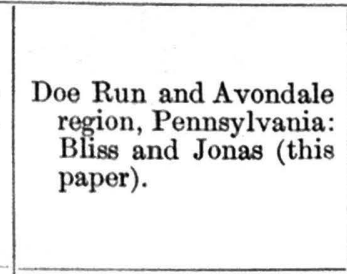 } & \multirow{3}{*}{$\begin{array}{l}\text { Philadelphia region: } \\
\text { Bascom( } \\
\text { folio). }\end{array}$} & \multicolumn{3}{|c|}{ New Jersey. } & \multirow{3}{*}{$\begin{array}{l}\text { Neww York City and } \\
\text { vicinity Merrili (New } \\
\text { York City folio). }\end{array}$} & \multirow{3}{*}{\multicolumn{2}{|c|}{$\begin{array}{l}\text { New England: Pumpelly, Wolfif, and Dale (Mono- } \\
\text { graph 23j). }\end{array}$}} \\
\hline & \multicolumn{2}{|c|}{ Keith. } & \multirow{2}{*}{ Campbell (Bristol folio). } & \multirow{2}{*}{$\begin{array}{l}\text { Darton (Franklin, Mon- } \\
\text { tery, } \\
\text { folioss). and staunton }\end{array}$} & & & & & & Spencer and Kümmel & Darton and Bavley (Pas. & & & \\
\hline & Nantahala folio. & Roan Mountain folio. & & & & & & & Dascom (1rention tonio). & \begin{tabular}{|l|l} 
folio). \\
forntioce
\end{tabular} & saic (olio). & & & \\
\hline \multirow{7}{*}{ Ordovician. } & & & & & & & & & & & & & & \begin{tabular}{|l|} 
Rowe schist. \\
\end{tabular} \\
\hline & & \begin{tabular}{|l} 
Athens shale. \\
\end{tabular} & Athens shale. & Martinsburg shale. & Martinsburg shale. & Absent. & Octoraro schist. & Octoraro schist. & Absent. & Martiusburg shale. & Hudson schist. & Hudson schist. & 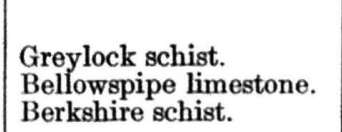 & Hoosac schist. \\
\hline & & Absent. & Chickamauga limestone. & \multirow{6}{*}{ Shenandoah limestone. } & \multirow{6}{*}{ Shenandoah limestone. } & \multirow{6}{*}{ Absent. } & \multirow{6}{*}{ Shenandoah limestone. } & \multirow{6}{*}{ Shenandoah limestone. } & \multirow{6}{*}{ Shenandoah limestone. } & Jacksonburg limestone. & \multirow{6}{*}{ Absent. } & \multirow{6}{*}{ Stockbridge dolomite. } & \multirow{6}{*}{\multicolumn{2}{|c|}{ Stockbridge limestone. }} \\
\hline & & Knox dolomite. & Knox dolomite. & & & & & & & \multirow{5}{*}{ Kittatinny limestone. } & & & & \\
\hline & & Nolichucky shale. & Nolichucky shale. & & & & & & & & & & & \\
\hline & & Honaker limestone. & Honaker limestone. & & & & & & & & & & & \\
\hline & $\begin{array}{l}\text { Nottely quartzite. } \\
\text { Andrews schist. }\end{array}$ & Watauga shale. & Russell formation. & & & & & & & & & & & \\
\hline \multirow[t]{4}{*}{ Cambrian. } & Murphy marble. & Shady limestone. & Absent. & & & & & & & & & & & \\
\hline & Valleytown formation. & Erwin quartzite. & Absent. & \multirow[b]{2}{*}{ Absent. } & \begin{tabular}{|l|} 
Antietam sandstone. \\
\end{tabular} & \multirow{3}{*}{ Absent. } & \multirow{3}{*}{ Chickies formation. } & \multirow{3}{*}{ Chickies quartzite. } & \multirow{3}{*}{ Chickies quartzite. } & \multirow{3}{*}{ Hardyston quartzite. } & \multirow{3}{*}{ Absent. } & \multirow{3}{*}{ Poughquag quartzite. } & \multirow{3}{*}{\multicolumn{2}{|c|}{ Vermont quartzite. }} \\
\hline & 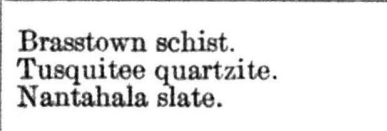 & Hampton shale. & Hampton shale. & & Harpers shale. & & & & & & & & & \\
\hline & $\begin{array}{l}\text { Great Smoky conglomerate. } \\
\text { Hiwassee slate. }\end{array}$ & Unicoi formation. & Unicoi formation. & & $\begin{array}{l}\text { Weverton andudstone. } \\
\text { Doudoun formation. }\end{array}$ & & & & & & & & & \\
\hline & & & & & & & Wissahickon mica gneiss. & Wissahickon mica gneiss. & \begin{tabular}{|l} 
Franklin limestone. \\
Wissahickon mica gneiss.
\end{tabular} & Franklin limestone. & Franklin limestone. & & & \\
\hline Pre-Cambrian. & Carolina gneiss. & Carolina gneiss. & & & & Carolina gneiss. & Baltimore gneise. & Baltimore gneiss. & Baltimore gneiss. & & $\begin{array}{l}\text { Garnetierous graphite } \\
\text { schist. }\end{array}$ & Fordham gneiss. & & \\
\hline
\end{tabular}




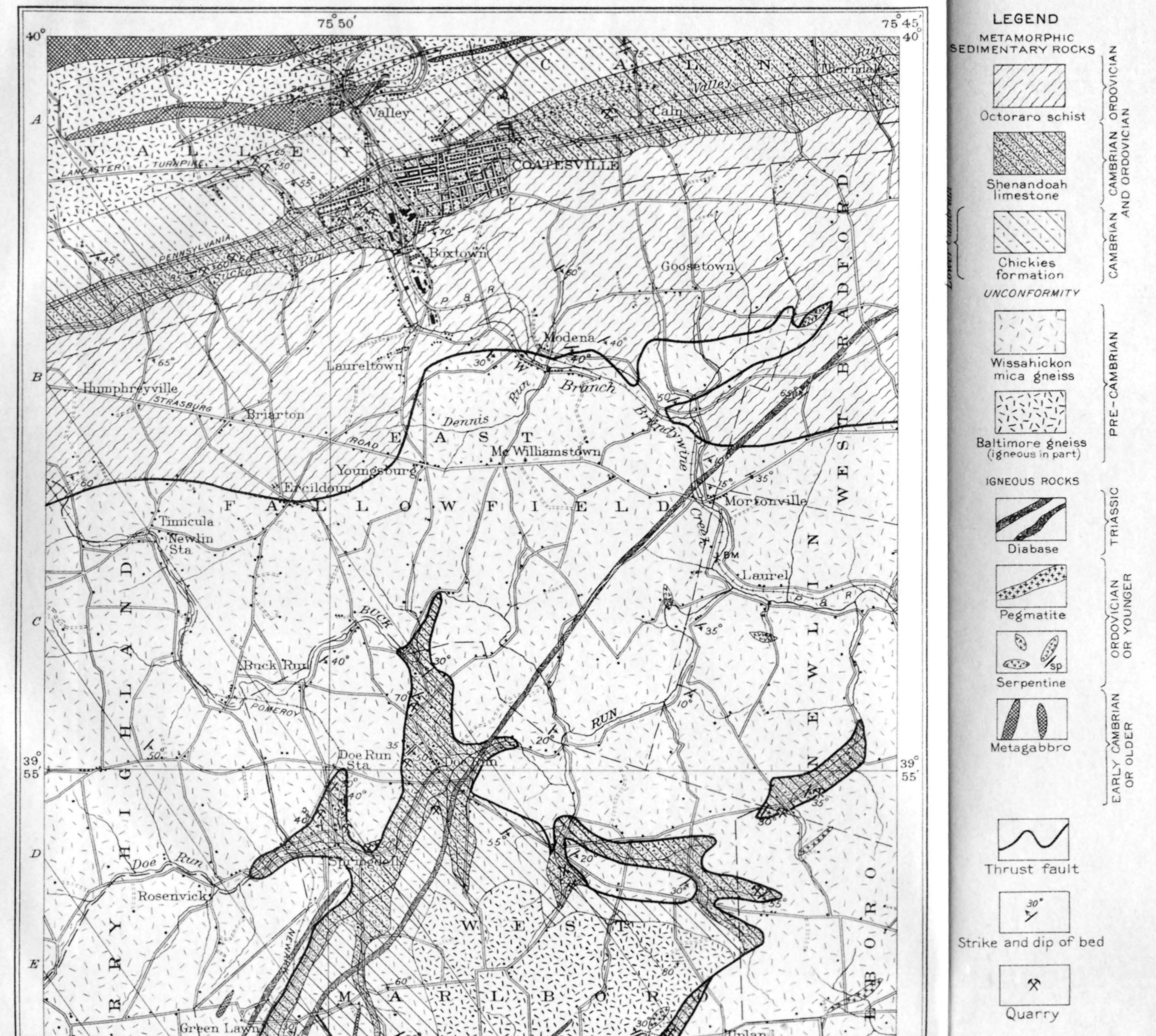


METAMORPHIC ROCKS.

PRE-CAMBRIAN.

BALTIMORE GNEISS.

Distribution.-In the Doe Run and Avondale region the Baltimore gneiss has a wide distribution at the surface: it occurs in three areas, one of which extends into both parts of the region. The most northerly area is north of Chester Valley, where gneiss underlies the northwest corner of the region and extends parallel to the strike from a point about a mile north of Caln southwestward to the western boundary of the area shown on the map. The second area, which is somewhat ellipsoidal in shape with its longest diameter extending in a northeasterly direction, lies in the central part of the Doe Run and Avondale region. Its northeast end is half a mile north of Upland, and its southwest end is a mile southwest of Chatham. The southernmost area extends south of the towns of Avondale and Westgrove to the southern boundary of the quadrangle. In this southern area it has been found difficult to make a satisfactory lithologic separation between the Baltimore gneiss and the Wissahickon mica gneiss and it may be eventually found that some of the rock mapped as Baltimore gneiss may prove to be Wissahickon gneiss.

Field relations.-The boundaries of the Baltimore gneiss are formed by younger formations - the pre-Cambrian Wissahickon mica gneiss, the Cambrian Chickies formation, or the Shenandoah limestone. The formation is penetrated by dikes of pegmatite and diabase, the latter intruded parallel to the strike of the country rock. The average strike of the Baltimore gneiss is N. $60^{\circ} \mathrm{E}$., and the dip of the schistosity $30^{\circ} \mathrm{SE}$. Its structure can be observed in stream gorges, in road cuts, and in the railroad cuts about Landenberg. The Baltimore gneiss produces a fertile soil, though it is made stony by the presence of slabs of the gneiss, which are colored a yellowish brown by iron oxide. South of Avondale, owing to a change in the character of the gneiss, the soil is sandy, dark colored, and full of black biotite.

Lithologic character.-The rock is a mediumgrained crystalline, massive or banded gneiss $30830^{\circ}-17-2$ composed of quartz, feldspar, biotite, and hornblende. The relative amount of each constituent varies widely; biotite may be abundant or scanty; hornblende may be present with the biotite or may replace it. The more or less partial segregation of the leucocratic and melanocratic constituents in alternating layers gives the rock the gneissic structure. In many exposures the rock is entirely disintegrated but has the gneissic structure still preserved; the kaolinized feldspar shows in white bands defined by the dark constituents of the rock.

The Baltimore gneiss is composed of an igneous and a sedimentary facies which it has been found impossible to separate in mapping. The igneous facies occurs in the center of the Baltimore gneiss area north of Coatesville and in a few scattered bowlders a mile southeast of Springdell and about a mile south of Clonmell. This rock weathers into spheroidal bowlders and lacks the banding which is characteristic of the main mass of the Baltimore gneiss in this region. The sedimentary facies is a light-gray banded gneiss containing considerable quartz and a varying amount of melanocratic constituents; a micaceous variety occurs in which. the mica is abundantly developed along planes of schistosity. Thin sections of the sedimentary Baltimore gneiss show the accessory minerals apatite, zircon, and magnetite in slightly rounded or waterworn forms. Quartz in a hornstone structure emphasized by iron oxide stain forms a groundmass in which are small blades of brown biotite whose longer axes have a generally parallel orientation. Feldspar occurs in fresh xenomorphic individuals of orthoclase, microcline, and oligoclase.

Analyses.-The following analyses were made on specimens of the Baltimore gneiss outside of the Avondale region-No. 1 representing samples obtained at six localities in the Philadelphia region and Nos. 2 and 3 the Baltimore gneiss of the Germantown quadrangle, where only the igneous facies is found. The analyses with low alumina, lime greater than magnesia, and soda greater than potassa indicate a rock of igneous character. 
Analyses of Baltimore gneiss.

\begin{tabular}{|c|c|c|c|}
\hline & 1 & 2 & 3 \\
\hline 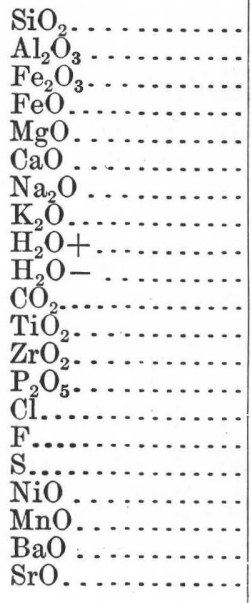 & 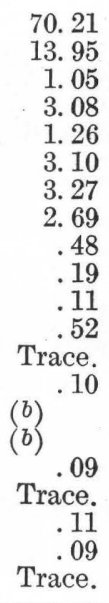 & 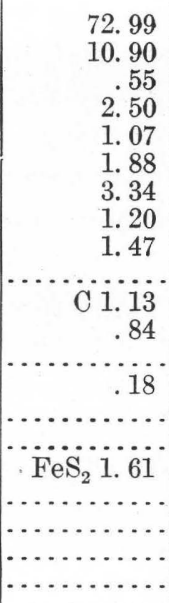 & 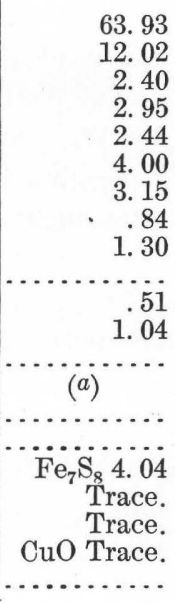 \\
\hline & 100.30 & 99.66 & 98.62 \\
\hline
\end{tabular}

1. Analysis by W. F. Hillebrand, U. S. Geological Survey. Bascom, Florence, Piedmont district of Pennsylvania: Geol. Soc. America Bull., vol. 16, p. 295, 1905.

2 and 3. Analyses by F. A. Genth, jr., Pennsylvania Second Geol. Survey Rept. C6, pp. 116, 105, 1881.

The following norm is obtained by recalculation of analysis 1 :

Norm of Baltimore gneiss.

Corundum........ $0.20 \mid$ Ilmenite.......... 1.06

Quartz............. 30.48 Pyrite............ . 18

Orthoclase........ 16.68 Magnetite......... 1.62

Albite............ 27.77 $\mathrm{H}_{2} \mathrm{O} \ldots \ldots \ldots \ldots \ldots . .67$

Anorthite......... 14.46 $\mathrm{CO}_{2} \ldots \ldots \ldots \ldots \ldots . .11$

Hypersthene....... 6.90

Apatite............. .34 100.47

The rock falls into Class I, order 4, rang 3, subrang 4-that is, the salic constituents are preponderant over the femic, the feldspar is dominant over the quartz, the potassa-soda percentage exceeds the lime, and finally, of the alkalies, soda is only a little in excess of the potassa. The rock is a biotitic hornblende granoyellowstonose.

The analysis of the Baltimore gneiss in its massive facies shows a rock of igneous origin. This rock is a remnant of the ancient central portion of the formation, which is found in the Baltimore gneiss of the area north of Coatesville. The Baltimore gneiss northwest of London Grove is thought to be of sedimentary origin, although derived from igneous material with little reworking. In pre-Cambrian time, by secular disintegration, such as takes place readily in a moist climate and in a country of slight topographic diversity, a soil was formed over the old igneous Baltimore gneiss land mass. By transgression of the sea the soil and underlying disintegrated rock were removed, reworked, and subsequently covered by other deposits. The rock formed by the consolidation and recrystallization of this material resembles the original rock in its constituents but possesses sedimentary rather than igneous characteristics. Folding has united the original and derived rocks into a complex that is difficult to separate into well-defined areas of igneous and sedimentary rocks. A formation similarly developed among the pre-Cambrian gneisses of Hoosac Mountain has been described by Pumpelly. 1

Thickness.-As the Baltimore gneiss represents the remnant of the pre-Cambrian gneiss floor upon which sediments of later age were laid down, its thickness can not be estimated.

Age and correlation.-Stratigraphic relations determine the pre-Cambrian age of the Baltimore gneiss; the formation is overlain by Cambrian sediments, from which it is everywhere separated by an unconformity.

The gneiss has been called Baltimore because of its correlation with gneiss exposed at Baltimore, Md., and has been recognized as the partial equivalent of the Fordham gneiss of New York, the Stamford granite gneiss of New England, and the Carolina gneiss of the South.

\section{WISSAHICKON MICA GNEISS.}

Distribution.-The Wissahickon mica gneiss covers the western and central portions of the Doe Run and Avondale region. Its northern boundary is the contact with the Octoraro schist, a line which runs northeastward from Timicula in a direction roughly parallel to the trend of the South Valley Hills. In the central and eastern parts of the Doe Run area of the formation it surrounds several bodies of limestone and quartzite, and north of Upland it occurs in two lenses bounded by limestone and quartzite. From the northwestern part of the Avondale district, west of the Baltimore gneiss and the Paleozoic formations, the Wissahickon is exposed continuously southward to the southern boundary of the Coatesville quadrangle.

1 Pumpelly, Raphael, The relation of secular rock disintegration to certain transitional crystalline schists: Geol. Soc. America Bull., vol 2, pp. 209-224, 1891. 
Field relations. - The usual strike of the mica gneiss lies between N. $60^{\circ}$ E. and N. $75^{\circ}$ E. The isoclinal dip of the cleavage and of the bedding is usually southeast, the prevailing dip of the rocks of the eastern Piedmont, and the average angle of dip is $35^{\circ}$. Stratification is a pronounced feature of the formation, and the strata are usually crumpled. In addition to cleavage planes transverse to the fine crumpling: of the strata, the mica gneiss has four systems of joint planes, parallel to which the rock breaks readily; thus it never weathers into bowlders but into angular fragments, producing a loamy clay soil full of rock fragments, of mica, and, in many localities, of garnets. From Jennersville southward through Kelton to the border of the quadrangle and eastward to Wickerton the soil is red, sandy, and sparkling with muscovite.

Although the Wissahickon gneiss crops out in many places, it weathers so readily as to afford few fresh exposures. It is generally exposed along stream beds, in road cuts, or in weathered cliffs projecting from hillsides that are covered by a mantle of heavy soil. It breaks readily into splintery fragments, which have been compared in appearance to halfrotted wood.

Lithologic character.-The Wissahickon mica gneiss is a silvery-gray to greenish medium to coarse grained schistose rock characterized by abundant muscovite and a varying amount of quartz and feldspar. Muscovite is developed either in minute crystals or in large glistening crystals which give the rock a spangled appearance. Garnets are a common constituent, and tourmaline is abundant.

The mica gneiss is intruded by dikes of metagabbro and pegmatite and, in some localities, is so thoroughly injected by these intrusives as to lose its peculiar characteristics. Where free from such injections the Wissahickon mica gneiss has the appearance of a metamorphosed sediment. A change in mineral constitution exists parallel to and is a means of recognizing the primary structure or bedding; where the bedding planes are finely plicated conspicuous unplicated transverse cleavage planes render the rock schistose and obscure the primary structure.

By microscopic study the feldspar is found to be orthoclase and andesine. The rock fails to show the sequence of crystallization of con- stituents which is peculiar to igneous rocks, and the accessory minerals, apatite and zircon, are present in rounded grains-both facts that point to a sedimentary origin for the rock. The absence of pressure effects in the quartz and feldspar also indicates that the rock is a recrystallized sediment.

This typical gneissic facies weathers to a greenish-brown rock in which the micaceous character is very conspicuous. It disintegrates readily, forming an argillaceous sandy soil that glistens with mica and is speckled with garnets. With local variations this gneiss, which is well exposed near Springdell in a road cut, is generally characteristic of the southern half of the main Wissahickon area.

Farther north, toward the schist boundary, the mica gneiss changes considerably in character. The fresh rock is fine grained, with bedding planes so thin that the rock assumes a schistose appearance, and the mica occurs in very fine crystals, evenly disseminated throughout the rock to such an extent as to obscure the other constituents. It weathers to a glistening green rock of schistose character, in which only the mica is visible on bedding planes, but on planes normal to the bedding the quartz and feldspar can be seen in very fine bands or in lenses wrapped about by the micaceous layers. Garnets are present in some of the rock. The weathered facies resembles the Octoraro schist, and where the two are adjacent they are difficult of separation. It differs from the schist, however, both in the presence of a characteristic crumpled bedding and also in the mode of occurrence, for it crops out along the roads and stream banks as high cliffs or strews the surface of the country in large slabs broken parallel to joint planes and contrasting with the small silvery fragments of the schist. A green slaty variety found at the northern boundary of the Wissahickon gneiss differs from the typical rock in its fine grain, extremely quartzose character, scanty feldspar, and abundant chlorite.

Analyses.-The best analysis obtainable of the mica gneiss was made by W. F. Hillebrand, of the United States Geological Survey, from four samples obtained at different localities in the Philadelphia region. ${ }^{1}$ It is

1 Bascom, Florence, Piedmont district of Pennsylvania: Geol. Soc. America Bull., vol. 16, p. 403, 1905. 
given in column 1 of the subjoined table. Analysis 2 was made by F. A. Genth, jr., from a specimen taken along Neshaminy Creek. ${ }^{1}$

Analyses of Wissahickon mica gneiss.

\begin{tabular}{|c|c|c|}
\hline & 1 & 2 \\
\hline 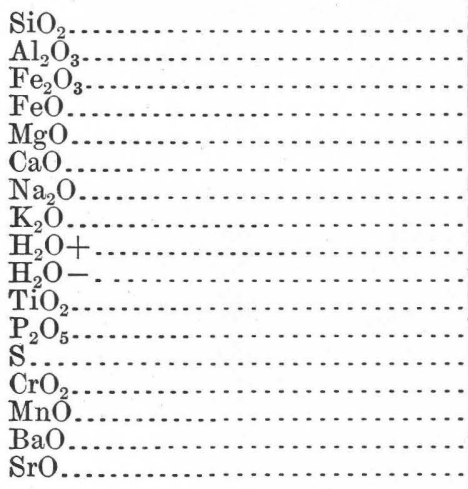 & $\begin{array}{r}66.13 \\
15.11 \\
2.52 \\
3.19 \\
2.42 \\
1.87 \\
2.71 \\
2.86 \\
1.55 \\
.24 \\
.82 \\
.22 \\
.03 \\
\text { None. } \\
.20 \\
\text { Trace. } \\
\text { Trace. }\end{array}$ & $\begin{array}{r}56.40 \\
19.76 \\
4.35 \\
4.40 \\
3.11 \\
.09 \\
5.82 \\
1.27 \\
3.37 \\
1.05 \\
.37 \\
\text { Trace. } \\
\text { Trace. } \\
\text { Trace. } \\
\text { Trace. }\end{array}$ \\
\hline & 99.87 & 99.99 \\
\hline
\end{tabular}

Origin.-The Wissahickon mica gneiss is considered to be a sedimentary rock whose origin has been obscured by extreme metamorphism. The rock has an original stratification, more or less perfectly preserved, which is more apparent where the cleavage, usually parallel, is discordant to the bedding. Other proofs of its sedimentary origin brought out by microscopic study have been mentioned.

That the Wissahickon mica gneiss has been derived from an arkosic argillite is to be inferred from its chemical composition. In the belt of weathering the underground and superficial waters carry materials in solution and suspension, and the materials that are easily soluble are not likely to be present in mechanical sediments, which represent the residual materials after solution has done its work more or less thoroughly and which therefore consist of members of the kaolin group, and serpentinetalc group, of quartz, aluminum oxide minerals, and acidic feldspars. An argillite, therefore, would be deficient in the alkalies and alkaline earths and more deficient in sodium and calcium than in potassium and magnesium, the percentage of alumina would be large, and after metamorphism the rock would retain its original chemical composition.

\footnotetext{
${ }^{1}$ Pennsylvania Second Geol. Survey Rept. C6, p. 109, 1881.
}

The analyses of the mica gneiss show such characters as have been described-alumina is high, magnesia is greater than lime, and potassa is greater than soda. This arkosic mud, by crystallization and metasomatism, has been metamorphosed into a mica gneiss. The feldspathic material has produced feldspar; the ferromagnesian material, muscovite; the sand has furnished the quartz, and a gneiss is the result.

Its more gneissic facies is due to injection of material parallel to the bedding. Pressure has caused reorientation of the old minerals with their longest axes in a plane normal to the pressure and the production of the new minerals with similar orientation. The muscovite, because of its perfect basal cleavage, is the mineral to which is due mainly the production of rock cleavage and fissility.

Thickness.-The thickness of the Wissahickon mica gneiss can not be exactly determined. Its isoclinal dip with repeated folding gives the impression of great thickness, but the actual thickness is difficult to estimate because the formation is an ancient preCambrian gneiss bounded above by an unconformity. Its estimated thickness has been placed between 1,000 and 2,000 feet.

Age and correlation.-In the absence of fossil content the determination of the age of the Wissahickon gneiss must depend upon the stratigraphic relations, which have been much obscured in the eastern Piedmont region; these relations, which are discussed at length elsewhere (pp. 31-34), point to a pre-Cambrian age for the Wissahickon gneiss of the Doe Run and Avondale region. The Wissahickon mica gneiss is correlated with portions of the Carolina gneiss.

Name.-The name Wissahickon was given to this formation on account of its fine exposures along the banks of Wissahickon Creek, near Philadelphia.

\section{CAMBRIAN.}

CHICKIES FORMATION.

Distribution.-The Chickies formation, of which quartzite is the most conspicuous member, associated with gneissic and schistose bands, forms the steep ridge of the North Valley Hills, extending across the north- 
western part of the Doe Run district (fig. 4) in gneiss is brought to the surface north of a straight band of almost uniform width, Coatesville.

whose general direction is parallel to the trend In the neighborhood of Doe Run the quartzof Chester Valley. On the south the quartzite ite comes to the surface as a band of varying
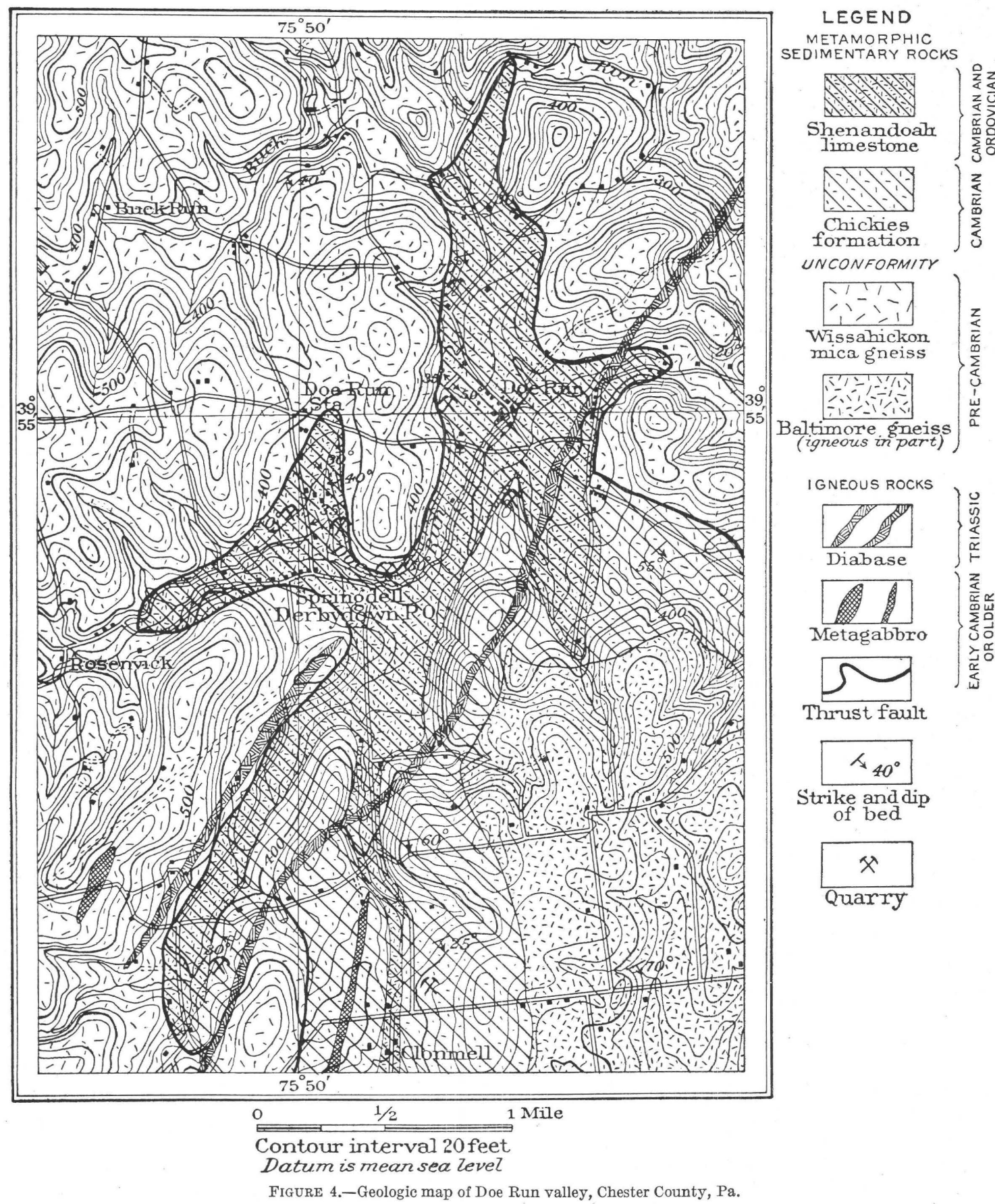

Thrust fault
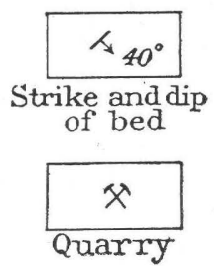

passes conformably under the Shenandoah|thickness which overlies the northeastern, limestone of Chester Valley; on the north it northern, western, and southern flanks of the overlies the Baltimore gneiss. The limestone and the quartzite together form the southern Baltimore gneiss.

North of Avondale and Toughkenamon anlimb of an anticline whose core of pre-Cambrian other area of the Chickies formation is bounded 
by limestone. The formation also forms a ridge north of Westgrove.

Field relations.-The hardness and chemical stability of the Chickies formation make its outcrop a prominent topographic feature. The rock is well exposed in several quarries in the North Valley Hills; on the road going southwest from London Grove, where two quarries are cut in the northern face of the hill; and in the quarries of the hill north of the State road from Avondale to Toughkenamon. The general strike of the formation is $\mathrm{N} .60^{\circ} \mathrm{E}$. and the dips are in all observed exposures to the southeast with an average inclination of $20^{\circ}$. At the contacts of quartzite and limestone the limestone appears to underlie the quartzite, a relation which is the result of overturned folding.

Lithologic character.-The Chickies formation is composed of quartzite, mica schist, and mica gneiss. The quartzite is a cream-white to gray fine-grained crystalline thin-bedded rock. Sericite is developed parallel to the bedding planes and causes the rock to split easily into flat slabs. The mica gneiss member of the formation is a gray fine-grained crystalline, slightly banded gneiss, whose constituents are quartz, biotite, and muscovite abundantly present and feldspar sparingly so.

With an increase in the amount of mica the rock becomes a mica schist, a pinkish or grayishgreen rock in which small sparkling plates of mica produce a frosted effect. This Cambrian mica schist resembles the Wissahickon mica gneiss, but the mica in the schist is usually present in smaller flakes than it is in the gneiss, and the Cambrian rock, in distinction from the Wissahickon, has straight bedding planes. The two rocks are further distinguished by structural relations and by a characteristic aspect that is difficult to define. "Stretched" tourmaline-that is, broken and linearly displaced tourmaline-is found in all three members of the Chickies formation.

The quartzite of the North Valley Hills is a pure hard white compact fine-grained, heavily bedded rock, with abundant small flakes of glistening sericite developed along the bedding planes. In the neighborhood of Doe Run the Cambrian formation is represented by the quartzose and schistose members. Near Springdell it is represented by the mica gneiss.
All these facies occur in the Chickies formation as exposed on the western and southern flanks of the Baltimore gneiss anticline. The Chickies northeast of Avondale and Westgrove is the mica gneiss facies, in which abundant mica is disseminated throughout the rock.

Microscopic study shows that the feldspar is largely microcline, but orthoclase, andesine, and bytownite are also present. Magnetite, zircon, pyrite, titanite, perofskite, and tourmaline are accessory constituents.

Analysis.-The analysis of a specimen of quartzite from the ridge south of Langhorne, $\mathrm{Pa}$., is given below. ${ }^{1}$ It shows high silica content and sufficient alumina and potassa to form muscovite and feldspar.

Analysis of quartzite of Chickies formation.

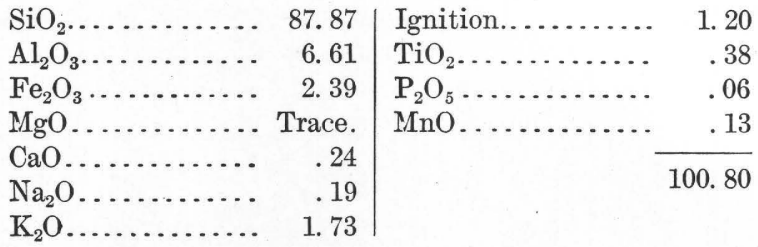

Thickness. - The close isoclinal character of the folding makes the determination of the thickness of this formation difficult. Its estimated thickness in Chester Valley is 1,300 feet, ${ }^{2}$ but in the Doe Run district a thickness of 1,500 feet seems probable. The section exposed on the DoeRunroad represents a deposit of about 1,000 feet. (See Pl. II, B.) Within the Avondale area (fig. 5) the thickness of the Chickies formation varies from 700 to 800 feet. The variability in thickness of the formation in the region south of Chester Valley is presumably due to original irregularity of deposition in the estuaries of the Cambrian sea.

Age and correlation.-The quartzite of the North Valley Hills forms a continuous band which extends from the western edge of Bucks County to the vicinity of Gap, in Lancaster County. Borings of Scolithus linearis have been found at several places in the quartzite of the North Valley Hills, which is in direct stratigraphio continuity with the quartzite near Coatesville. In 1896 Walcott $^{3}$ deter-

1 Pennsylvania Rept. Second Geol. Survey C6, p. 117, 1881. Analysis by F. A. Genth, jr.

2 Bascom, Florence, U. S. Geol. Survey Geol. Atlas, Philadelphia folio (No. 162), p. 4, 1909.

${ }^{3}$ Walcott, C. D., The Cambrian rocks of Pennsylvania: U. S. Geol. Survey Bull. 134, p. 17, 1896. 


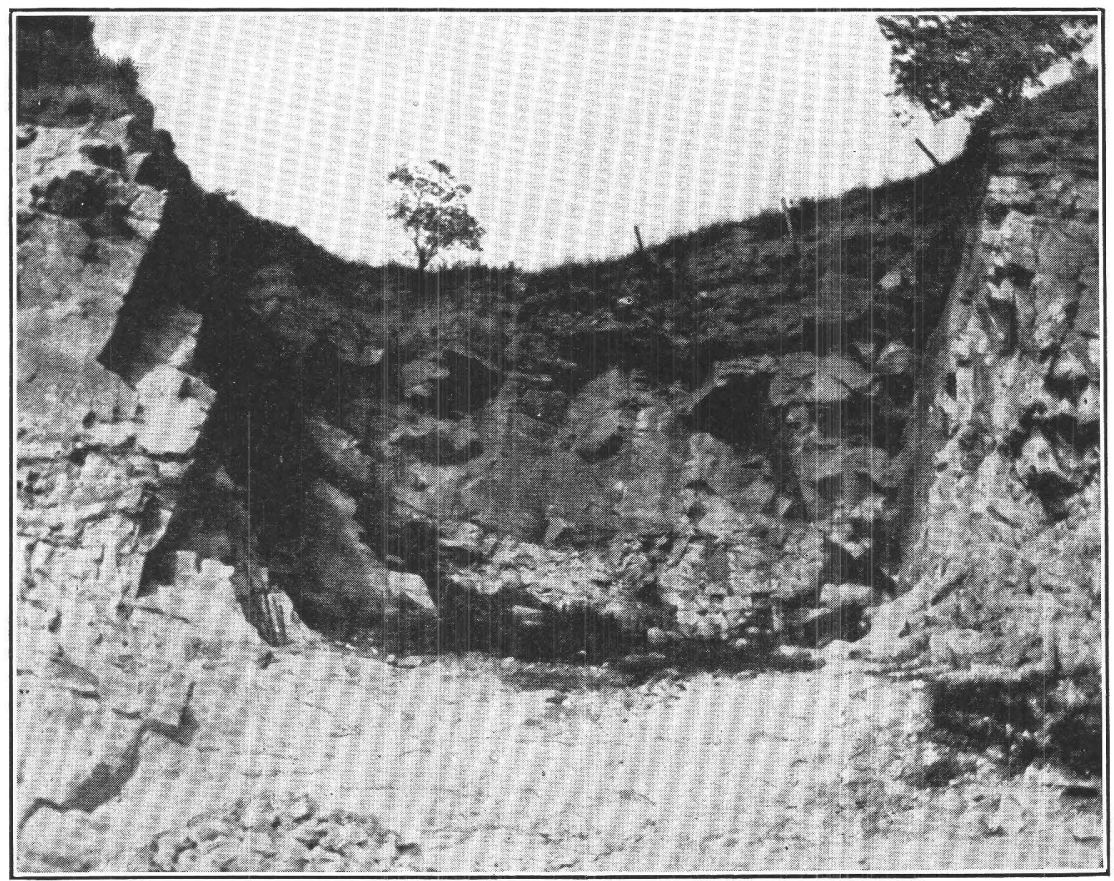

A. QUARRY IN SHENANDOAH LIMESTONE, $1 \frac{1}{2}$ MILES SOUTHEAST OF DOE RUN, CHESTER COUNTY, PA.

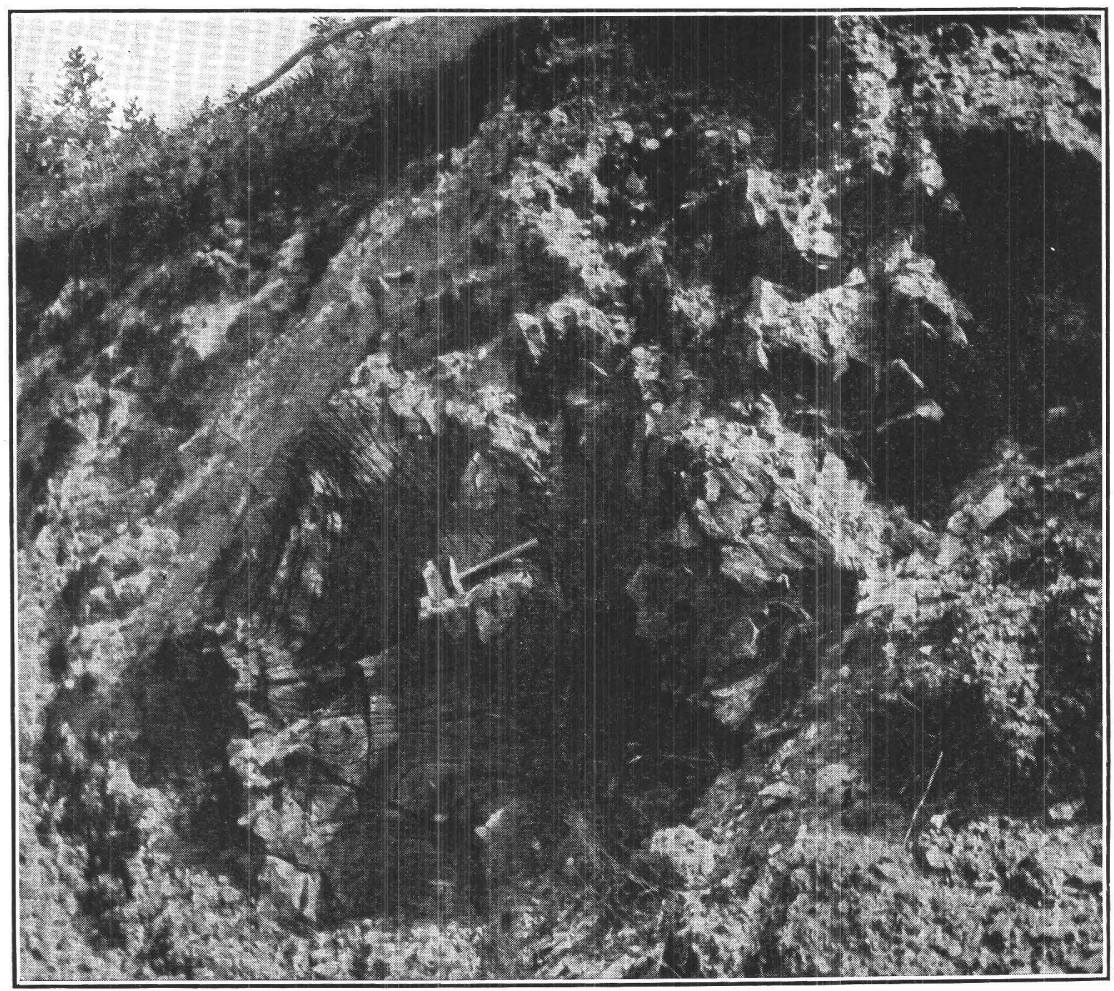

B. SECONDARY FOLDS ON LIMB OF ANTICLINE IN CHICKIES FORMATION ON DOE RUN ROAD, CHESTER COUNTY, PA. 

mined the position of the Scolithus-bearing quartzite as underlying shales and calcareous sandstone which contain fragments of Olenellus. This determination establishes the age of the Scolithus-bearing rock as Lower Cambrian. The rock south of the North Valley Hills does
Name.-The name Chickies (formerly spelled Chikis) was first used to describe the rock exposed on Susquehanna River near Columbia, Lancaster County. Later the spelling was determined as Chickies by the United States Geographic Board.
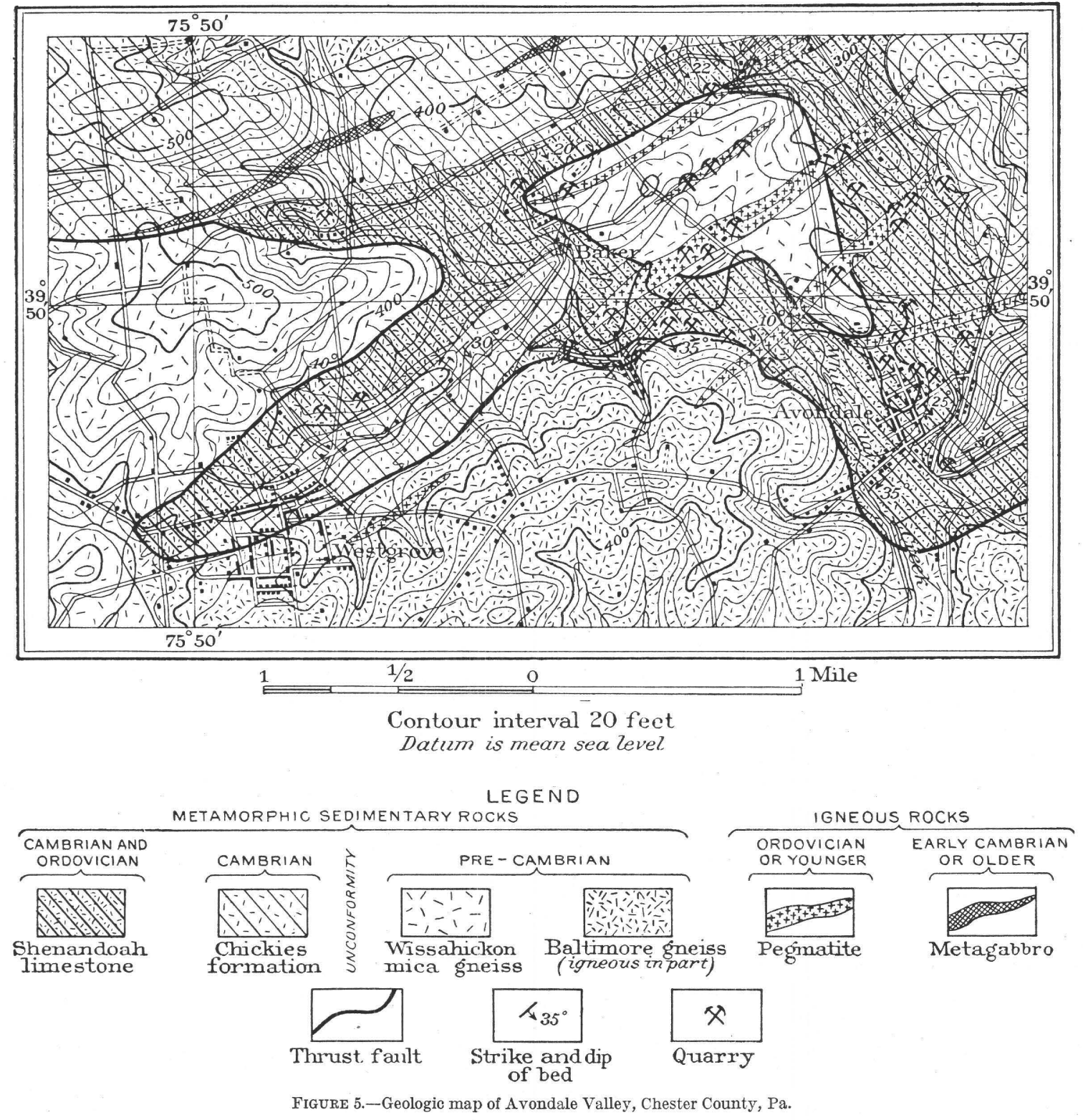

not contain Scolithus linearis, but from its lithologic character and structural relations may be correlated with the Chickies quartzite of the North Valley Hills. The formation has been correlated with the Cheshire ("Poughquag") quartzite of New York, the Hardyston quartzite of New Jersey, and the Setters quartzite of Maryland.

\section{CAMBRIAN AND ORDOVICIAN.}

\section{SHENANDOAH LIMESTONE.}

Distribution and field relations.-In the northern part of the Doe Run district (see Pl. I, p. 10) the outcrop of Shenandoah limestone corresponds perfectly to the floor of Chester Valley, forming a narrow belt, which 
varies in width from one-fourth to threefourths of a mile. On the north side of the valley the limestone overlies the quartzite, which is exposed on the southern limb of an anticline. Toward the south the limestone passes conformably under the Octoraro schist of the South Valley Hills.

In the central and southern parts of the Doe Run district limestone occurs in four distinct areas of irregular conformation. The largest area extends from Buck Run almost due south to Doe Run village, where the outcrop is pierced by an anticlinal hill of resistant quartzite. From Doe Run southwest to Green Lawn there is a continuous outcrop of limestone, and from Springdell directly south limestone joining the western flank of the quartzite occurs in a long valley that extends to the southern edge of the Doe Run district.

On the northern and northeastern boundary of the quartzite the limestone occurs in two small but distinct outcrops at Guest's and Logan's quarries. (See Pl. II, A.) The fourth occurrence is a narrow and irregular outcrop along a tributary of Brandywine Creek, about 2 . miles northeast of Logan's quarry and 1 mile north of Upland.

Except where it borders the quartzite the limestone of these areas is surrounded by the Wissahickon mica gneiss, thereby producing a radial and finger-like arrangement of the surface outcrops which is particularly striking. (See fig. 4.)

In the Avondale district (see fig. 5) the limestone occupies the valley of White Clay Creek about Avondale and to the north, and the valley of West Branch of White Clay Creek and its tributaries near Landenberg. The areas are not more than half a mile wide and are very irregular. The northern area extends southwestward for about 5 miles from the center of the eastern border of the Coatesville quadrangle; then it turns south and curves about a hill of mica gneiss which lies north of Westgrove; from that point it extends southward through Baker and southeastward to Avondale, where it connects with two belts of the formation-one from the east along Trout Run and the other from the north. (See fig. 5.) About a mile south of Landenberg there is a small area of limestone extending southwestward along Broad Run and across White Clay Creek almost to West Branch. It is not more than a mile wide anywhere and does not appear at the surface except at Nevin's quarries.

As there are no natural outcrops of the limestone, its extent is best determined by the soil it makes-a red clay such as is formed by the weathering of a magnesian lime rock. It is exposed for the most part in abandoned quarries which are partly filled with water; the rock forming the walls may be fresh or partly disintegrated into calcareous sand or almost entirely covered by a talus of soil. In the region of Baker and Avondale there are large quarries which are now being operated in this rock and which furnish valuable marble and building stone.

The strike of the formation ranges between N. $60^{\circ} \mathrm{E}$. and N. $70^{\circ} \mathrm{E}$. The direction of dip is generally southeast, the only prominent exception being a northwest dip found in a small quarry just north of Westgrove. The angle of dip is low, varying from $20^{\circ}$ to $25^{\circ}$.

Lithologic character.-Three varieties of the Shenandoah limestone are recognizable in the Doe Run and Avondale region. One occurs in Chester Valley, where the fresh rock is a massive, highly crystalline blue magnesian limestone, which breaks readily along three joint planes. Few accessory minerals are found in this massive variety. The upper member of the formation in this area is a highly micaceous and thinly bedded schistose rock, in which quartz and mica are so abundant that the rock may be called a calcareous schist. This member grades into the overlying Octoraro schist.

The third variety occurs in the central belt of limestone, where it is well exposed in Guest's and Logan's quarries, and in the limestone of the Avondale district. Where pure the fresh rock is a medium-grained, highly crystalline lustrous white saccharoidal marble, characterized by the abundant development of various accessory minerals. Phlogopite, in glistening amber-brown scales, is in some places so plentiful that, on planes parallel to the bedding, the rock may appear to be composed almost entirely of mica. Where the phlogopite occurs in smaller flakes it gives the rock a variegated appearance, which has won for it the name "bastard granite." Biotite, muscovite, tour- 
maline in large black crystals, magnetite, apatite, and pyrite are common accessory - minerals.

Evidences of pressure seen in the thin section are twinning of the calcite crystals, granulation, and undulatory extinction of the quartz, which occurs in interlocking areas forming a mosaic with the calcite. The dolomite of Chester Valley is finer grained than the limestone of the southern area, which in Guest's quarry is almost pure calcite.

Analyses.-Some analyses of the limestone are given below:

Analyses of Shenandoah limestone.

\begin{tabular}{|c|c|c|c|c|}
\hline & 1 & 2 & 3 & 4 \\
\hline 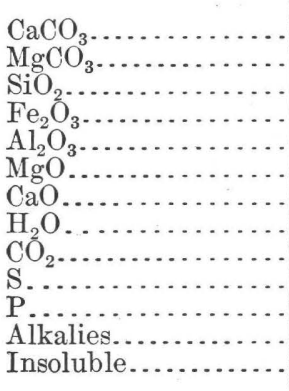 & 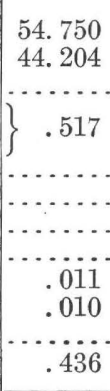 & $\left\{\begin{array}{r}40.27 \\
31.24 \\
24.23 \\
1.06 \\
1.12 \\
.11 \\
.55 \\
\ldots \ldots\end{array}\right.$ & $\left\{\begin{array}{c}54.071 \\
43.309 \\
\cdots \cdots \\
\ldots \\
.621 \\
\cdots \cdots\end{array}\right.$ & 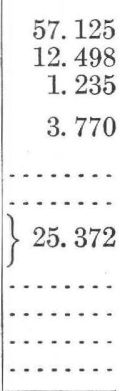 \\
\hline & 99.928 & 100.00 & 99.959 & 100.000 \\
\hline
\end{tabular}

1. Haldeman South quarry, near Chickies. Best blue limestone, fine grained, hard. Analyst, A. S. McCreath, Pennsylvania Second Geol. Survey Rept. CC, page 271, 1874.

2. West Conshohocken, Montgomery County, Pa. Analyst, F. A. Genth, jr., Pennsylvania Second Geol. Survey Rept. C6, page 126, 1881.

3. Benjamin Swayne quarry, 2 miles north of Avondale. Analyst, F. A. Geuth, jr., idem, page 127.

4. Pennsylvania Marble \& Granite Co.'s quarry, Baker. Analysts, Booth, Garrett \& Blair, Philadelphia.

Thickness.-In the Avondale district the thickness of the limestone, which does not exceed 1,000 feet, represents only part of the original thickness; the remainder has been removed by erosion. In Chester Valley the formation is probably not over 1,500 feet thick.

Age and correlation.-In the central part of the region, at Guest's quarry, and in the northern part, in Chester Valley, the limestone conformably overlies the Chickies formation. On account of the highly metamorphosed character of the rock, fossils are rare in the Shenandoah limestone and none have been found in the Doe Run and Avondale region, but at Henderson station, Montgomery County, Pa., fossils of Ordovician age have been found in the limestone of Chester Valley. ${ }^{1}$

That the limestone of the Doe Run and Avondale region is to be correlated with the Cambrian and Ordovician Shenandoah limestone of Montgomery and Delaware counties is proved by the stratigraphic continuity of the limestone in Chester Valley, by marked lithologic resemblance between the limestone of the Doe Run and Avondale region and the rock in Chester Valley, and by the position of the limestone south of Chester Valley in approximately the same line of strike as the narrow belt of Shenandoah limestone in Cream Valley near Conshohocken, Pa.

Name.-The name Shenandoah was adopted by Darton ${ }^{2}$ in 1892 to designate the limestone formation of Cambrian and Ordovician age which occurs in the Appalachian region of Virginia. Subsequently the United States Geological Survey accepted the name because of its priority and applied it to the "Chester Valley" limestone and to the outcrops southeast of Chester Valley which had been correlated with the Shenandoah.

\section{ORDOVICIAN}

OCTORARO SCHIST.

Distribution and field relations.-The north face of the South Valley Hills forms the northern boundary of the outcrop of the Octoraro schist; the southern boundary is a line passing about half a mile north of the village of Timicula, through Ercildoun, a quarter of a mile west of Youngsburg, north to Modena, where it runs in a southeasterly direction to the eastern boundary of the Coatesville quadrangle.

The schist conformably overlies the Shenandoah limestone on the north, grading imperceptibly into the limestone through a calcareous lower member; on the south it adjoins the Wissahickon mica gneiss, the line of contact representing a fault which extends across the country in a roughly northeast direction. The average strike of the formation is $\mathrm{N} .65^{\circ} \mathrm{E}$. and the dips are about $60^{\circ} \mathrm{SE}$.

\footnotetext{
1 Bascom, Florence, U. S. Geol. Survey Geol. A.tlas, Philadelphia folio (No. 162), p. 5, 1909.

2 Darton, N. H., U. S. Geol. Survey Geol. Atlas, Staunton folio (No. 14), 1894.
} 
In topographic features the country underlain by the Octoraro schist is very similar to that formed by the erosion of the Wissahickon mica gneiss. The schist, like the gneiss, yields readily to the mechanical processes of weathering and forms a deep micaceous soil, which differs from the gneiss soil in that it does not contain individual flakes of mica, but rather small fragments of the rock that have not been disintegrated into the individual constituents.

The soil produced by the disintegration of the schist is dull and sandy, nongarnetiferous, and full of green, shiny fragments that have a soapy feel, but the gneiss soil is glistening and sparkling with large flakes of mica, abundantly garnetiferous, and less likely to be red. Another marked difference in the two formations is the method of disintegration. The Octoraro schist does not have the three wellmarked joint planes which cause the Wissahickon gneiss to break readily into parallelepipeds; but, having an easy cleavage along the planes of schistosity, it splits into thin laminated fragments.

Lithologic character.-The Octoraro schist may be described as a quartz-muscovite schist or a quartz-chlorite schist, in which the mineral constituents are so minute that on the cleavage planes no one mineral is distinguishable. The fresh rock is light silvery gray and very schistose in character and is composed of quartz and mica or chlorite. The quartz, which is visible only on the edge transverse to the cleavage plane, occurs in lenses completely wrapped around by the micaceous layers; on cleavage planes mica alone is visible in microscopic flakes that are indistinguishable in the hand specimen. These micaceous constituents form a surface with a smooth "feel," which has been described as "soapy." The color varies from gray in the fresh rock to green or yellow in the weathered rock.

In the thin section the schistose character of the rock is very apparent. Small grains of quartz, showing hornstone texture, form continuous bands throughout the rock or occur in lenses enveloped by twisted fibrous muscovite or muscovite and chlorite; muscovite may be present in fine blades and chlorite may be almost entirely absent, or muscovite and chloritized biotite may occur together, associated with secondary quartz, hematite, and magnetite. The accessory minerals are pyrite, magnetite, perofskite, titanite, rutile, and apatite.

The sedimentary origin of the schist is shown both in its field relations and in its composition. It is the upper member of a conformable series of sandstone, limestone, and shale, and has the restricted mineral content and hornstone texture of a sedimentary deposit that has undergone metamorphism.

Analysis.-The composition of the schist is shown by the following analysis:

Analysis of Octoraro schist.

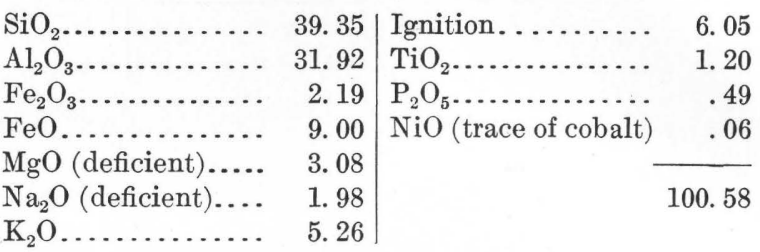

Mica schist, 1,222 feet from Bird in Hand Tavern, on road from Gulf Mills to Bryn Mawr, Montgomery County, Pa. Pennsylvania Second Geol. Survey Rept. C6, p. 133, 1881.

The small content of the alkalies and alkaline earths relative to the silica and alumina, the absence of lime, and the preponderance of potash over soda in the analysis point to a sedimentary origin of the formation in which the more readily soluble substances, such as lime, soda, and the alkalies, have been removed in solution.

Thickness.-In the syncline of the South Valley Hills the thickness of the Octoraro schist seems to be about 2,000 feet.

Age and correlation.-The Octoraro schist conformably overlies the Shenandoah limestone, grading down into the limestone through a calcareous schist, and is therefore of Ordovician age. It has been correlated with the Berkshire and Hoosac schists of New England.

Name.-The name Octoraro has been given to the schist because it is particularly well exposed along the banks of Octoraro Creek, between Lancaster and Chester counties.

IGNEOUS ROCKS.

EARLY CAMBRIAN OR OLDER.

METAGABBRO.

Distribution.-About a mile northwest of Coatesville the Baltimore gneiss is penetrated by two intrusive gabbro masses. Only the southern extremity of one intrusion is visible 
in the region under discussion; the other mass extends eastward from the western boundary of the region mapped (Pl. I) to Valley station, on Rock Run. A small dike occurs on the east side of Rock Run.

In the southern part of the Doe Run district and throughout the Avondale district metagabbro occurs in narrow dikes in the Baltimore and Wissahickon gneisses and the Chickies formation. The outcrops of the dikes north of Arondale range in width from a few feet to half a mile. About Wickerton, New Garden, and Landenberg the dikes are of considerable size. South of Landenberg a series of narrow dikes, roughly parallel in direction, may be traced for 5 or 6 miles southwestward to the southern edge of the Coatesville quadrangle.

Field relations.-The dikes of hornblende gneiss cut the country rock with varying strike, and are in places weathered into a soft darkgreen rock in which hornblende may still be distinguished.

Lithologic character.-The rock of the two areas northwest of Coatesville is a holocrystalline, granular, or only slightly gneissic medium to fine grained gabbro. The only constituents visible to the naked eye are plagioclase, a darkgreen pyroxene, and brown hornblende in slender crystals. The metagabbro is a fine-grained dark-colored rock, for the most part green to greenish black, with leucocratic constituents mottling it. Lustrous hornblende, the most abundant and conspicuous constituent, has a parallel arrangement and thus gives the rock a banded appearance. The feldspar occurs in minute grains of a dull chalky aspect. In thin section it is found that this aspect of the feldspar is due to saussuritization, which obscures the original character of the feldspar. The character of the extinction angle indicates that the feldspar is labradorite-bytownite. Hornblende has been formed by uralitizationthat is, by the alteration of the original augite into hornblende. A core of augite is present in the interior of some of the hornblende crystals, where its pale-green to colorless character, its high index of refraction, and its occasional basal sections with rectangular cleavage separate it sharply and conspicuously from the surrounding hornblende. The gneiss, with its basic feldspar, uralitized augite, and accessory zircon, has the constitution of a quartz-augite gabbro. It is at present a metagabbro or, because of its secondary banding, a hornblende gneiss.

Analysis.--The following analysis ${ }^{1}$ represents a dike of similar metagabbro which occurs a mile north of Bryn Mawr station:

\section{Analysis of metagabbro.}

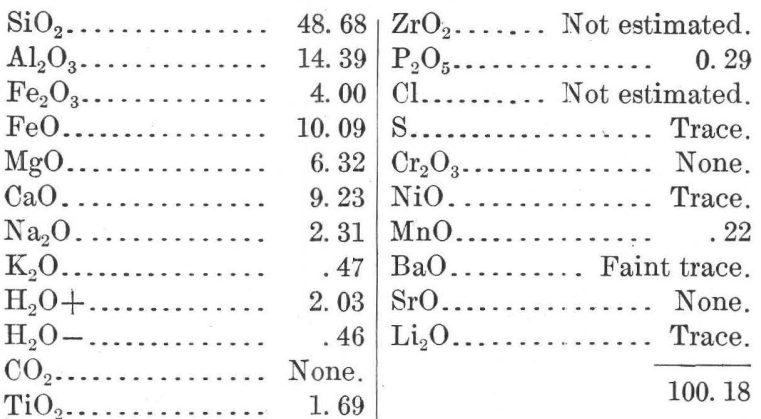

The analysis gives the following norm:

Norm of metagabbro.

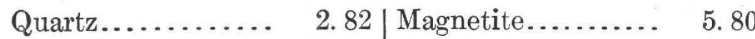

Orthoclase......... 2. 78 Ilmenite......... 3. 19

Albite.......... 19.39 Apatite........... .67

Anorthite......... 27.52 Water........... 2. 49

$\begin{array}{lr}\text { Diopside............ } & 13.67 \\ \text { Hypersthene....... } & 21.78\end{array}$

The rock falls in Class III, order 5, rang 4, and subrang 3 and is a hornblende granoauvergnose; it is perfelic, docalcic, and presodic. The compound prefix is given because hornblende is the only abnormative mineral and because the texture of the rock is hypautomorphic granular.

Origin.-There can be no question of the igneous origin of the metagabbro, for the field relations, mineral constituents, and chemical composition concur in pointing to such an origin. Since the intrusion and consolidation of the gabbro pressure has converted the augite into hornblende and has produced a rock cleavage parallel to the prevailing southeastward dip of the cleavage of the region.

Age.-The gabbro has nowhere been found intruded into recognized Paleozoic sediments, but large masses of gabbro have been found in pre-Cambrian rocks throughout the eastern Piedmont belt, and it can therefore be regarded as belonging to the period of preCambrian igneous activity. The presence of a

1 Geol. Soc. America Bull., vol. 16, p. 319, 1905. Analyst, W. F. Hillebrand, U. S. Geol. Survey. 
dike of hornblende gabbro in the Chickies formation makes it seem likely that a portion of the original magma which furnished the material for the pre-Cambrian intrusions may have been injected into fissures either during the period of Lower Cambrian deposition or at some later time.

\section{PRE-SILURIAN OR YOUNGER.} SERPENTINE.

Distribution and field relations.-The occurrence of serpentine in the Doe Run district is restricted to three small lenticular areas, which range in length from a quarter of a mile to half a mile, and are about one-eighth of a mile in width. Two of these areas are situated near Laurel, on the West Branch of Brandywine Creek, and the third is about a mile southeast of Goosetown. The outcrops are nowhere prominent, being confined to cuttings in the hillsides near Laurel and to a few scattered bowlders in the fields near Goosetown. Owing to the small extent of the areas it is impossible to recognize the presence of serpentine by its characteristic thin soil and stunted vegetation. The lenticular shape of the areas and the character of the rock itself are evidences of its igneous origin. The Laurel outcrops are within the confines of the Wissahickon mica gneiss; the Goosetown outcrop is partly surrounded by the Ordovician schist. In the Avondale district there is a small outcrop of serpentine on the Toughkenamon and London Grove road $1 \frac{1}{2}$ miles north of Toughkenamon. The rock, which is exposed in a road cut, is only a few feet in width and does not reappear along the strike. The exposure is surrounded by Cambrian gneiss belonging to the Chickies formation.

Lithologic character.-The serpentine in the region of Laurel is a soft green, extremely talcose schist, almost approaching a soapstone; in the neighborhood of Goosetown it is a massive green serpentine. The thin section of the Goosetown rock shows that it is composed mainly of serpentine; other alteration products are talc, calcite, and iron oxides. The rock has been so completely altered to serpentine that the original character is difficult to determine, but a few small grains of residual olivine remain, showing that the rock was derived from a peridotite. The rock north of Toughkenamon is almost a tremolite schist; it is green in color, fibrous, and soft.

Age.-Throughout the eastern Piedmont district of Pennsylvania there are many serpentine dikes whose occurrence, except in the isolated areas near Goosetown and Toughkenamon, is restricted to pre-Cambrian rocks. In many places in the immediate vicinity of Philadelphia and around Chester and West Chester serpentine is intruded into the preCambrian gneisses, but it nowhere occurs in a formation later than the Wissahickon gneiss.

Owing to the common occurrence of serpentine in pre-Cambrian material and to its almost total absence from Paleozoic material, it seems possible that the serpentine near Goosetown, which is a metamorphosed peridotite, belongs to the pre-Cambrian period of igneous activity and that it was carried in a small patch of igneous material along with the overthrust Wissahickon gneiss over the surface of the schist and left by subsequent erosion. The area appears to be partly surrounded by the Wissahickon mica gneiss, but the cultivation of the farm land in which the serpentine occurs makes it difficult to map the border accurately. The irregular character of the boundary between the Wissahickon gneiss, serpentine, and Octoraro schist is such as would be expected to result from the partial removal by erosion of the overlying rock. It is possible that the serpentine of the area north of Toughkenamon is a remnant of overthrust pre-Cambrian material left by erosion, or that it is a land area which remained an island during the whole or part of Cambrian and Ordovician time.

In Syracuse, N. Y., serpentine occurs in the Salina formation, of Silurian age, formerly called "Onondaga salt group," and Williams ${ }^{1}$ has called attention to the fact that this serpentine bears a strong resemblance to the Carboniferous peridotites of Kentucky described by Diller. ${ }^{2}$ The occurrence of postCarboniferous serpentines in the Appalachian province suggests that the serpentine here discussed may possibly be of later age than

1 Williams, G. H., On the serpentine (peridotite) occurring in the Onondaga salt group at Syracuse, N. Y.: Am. Jour. Sci., 3d ser., vol. 34, p. $137,1887$.

2 Diller, J. S., Peridotite of Elliott County, Ky.: U. S. Geol. Survey Bull. $38,1887$. 
Ordovician and therefore intrusive in the Octoraro schist of the Doe Run district and in the Cambrian gneiss of the Avondale district. In view, however, of the absence of conclusive evidence showing the Paleozoic or post-Paleozoic age of the serpentine in the Goosetown and Toughkenamon areas, and in view of the preponderance of igneous material in the pre-Cambrian rocks, it seems impossible to determine the age of the serpentine without further discovery of its occurrence in Paleozoic material.

\section{PEgMatite.}

Distribution and field relations.-Pegmatite occurs at eight places in the Doe Run district. Four dikes extend across the country in the neighborhood of Coatesville, striking northeast. Three of these dikes occur northeast of the town, showing themselves in bowlders scattered through the fields; the fourth, which lies directly east of Coatesville, is a seam of kaolin within the confines of the limestone. Of the four pegmatite localities in the southern part of the Doe Run district, three lie in a continuous line northeast of Upland. There are only two direct outcrops of the rock in the Doe Run district. One is an old spar pit on the Sharpless farm at Upland; the other, in direct line of strike with the first, is a dike of quartz-feldspar rock in Logan's limestone quarry.

The Avondale district contains many pegmatite dikes. With the exception of an isolated outcrop north of Chatham, the areas of pegmatite north of Avondale may be grouped into five dikes, the largest of which is an eighth of a mile wide. The northernmost dike appears a mile south of London Grove, whence it may be traced to Baker; the other four lie to the southeast, each separated from the next by about half a mile and the southernmost cropping out just north of Avondale. Between Avondale and Landenberg the pegmatite dikes are scattered and small, but south of Landenberg, in the neighborhood of the limestone, four dikes cut the metagabbro, the Baltimore gneiss, and the Shenandoah limestone. Many other dikes too small to be mapped cut the country rock of that region.

Lithologic character.-The pegmatite is a coarse-grained white to gray rock composed of quartz, light-gray or pink feldspar, and abundant muscovite in large plates. The feldspar when fresh has lustrous surfaces but when weathered is abundantly coated with a yellow iron oxide stain. The feldspar may be orthoclase with Carlsbad twinning or, more rarely, with twinning according to the Baveno law; or microcline with the gridiron texture; or oligoclase; or microperthite. The most prominent of the long list of accessory minerals associated with the pegmatite are iron pyrites, tourmaline, and garnet.

The absence of banding, the coarse crystallization, and the diversity in texture and mineral composition are all evidences that the pegmatite is not a normal plutonic rock which has undergone the pressure to which the other rocks of the region have been subjected. On the other hand, the trend of the dikes, discordant to the strike of the country rock, is unlike that of the veins of the region.

Origin.-The pegmatite dikes of this region represent the most highly differentiated phase or end product of an igneous magma. They show more igneous than aqueous characteristics and may be explained as the result of slow crystallization of an igneous magma saturated with water. They are the youngest pre-Triassic igneous rocks of the region and represent the expiration of the igneous activity which began in pre-Cambrian time and which is represented in the Coatesville region by the metagabbro and in the Philadelphia region by the porphyritic granite, gabbro, and ultrabasic peridotite and pyroxenite.

The points of difference between pegmatites and piutonic rocks have already been mentioned. The pegmatite is coarse and irregular in texture and has not the uniform constitution of a granite. It is like a granite in its order of crystallization and like a dike in its occurrence in the field.

Age.-The pegmatite has not been found in rocks younger than the Shenandoah limestone. Its intrusion was subsequent to the pressure that produced the thrust fault of the Wissahickon mica gneiss, and its age may be preSilurian or younger.

\section{TRIASSIC}

DIABASE.

Distribution and field relations.-Diabase occurs in five dikes in the Doe Run and Avondale region. One line runs through the Doe 
Run district in a southwesterly direction from a locality about $1 \frac{1}{2}$ miles southeast of Goosetown to the neighborhood of Green Lawn, and the great trap dike of Downingtown, northeast of Coatesville, may be regarded as a continuation of it. West of this long dike a shorter one exuends from Springdell to Green Lawn. On each side of a line drawn from Woodville to Chatham a dike of diabase may be traced southwestward for about 4 miles. A fifth dike near Woodville extends for about $1 \frac{1}{2}$ miles. Except for a few ledges, the existence of the diabase is indicated only by a trail of bowlders across the country underlain by the rock. It strikes N. $45^{\circ} \mathrm{E}$., and the width of the dikes where exposures exist is about 20 feet.

Lithologic character.-The Downingtown dike is a rather coarse grained diabase, composed of crystals of plagioclase and green pyroxene. The rock of the dikes near Woodville is typical fine-grained diabase, in which the only mineral constituent recognizable with the naked eye is pale-green feldspar sparkling in a dark greenish-gray groundmass. Microscopic study shows that the feldspar is labradorite-bytownite and occurs in automorphic lath-shaped crystals so arranged as to produce the ophitic texture characteristic of diabase. The microscope also shows pyroxene, which is pale-green augite and unusually fresh and which occurs as xenomorphic individuals within the network of feldspar. The accessory minerals are magnetite, epidote, quartz, biotite, apatite, and chlorite, with secondary ilmenite. The rock has a conchoidal fracture and when exposed to the atmosphere for some time weathers into spheroidal bowlders with a yellow exterior and a greenish-gray interior.

Analysis.-The following analysis represents a specimen of the Conshohocken dike in West Conshohocken, Montgomery County, Pa.: ${ }^{1}$

Analysis of diabase from Conshohocken dike.

\begin{tabular}{|c|c|c|c|}
\hline $\mathrm{SiO}_{2} \ldots \ldots$ & 51.36 & $\mathrm{~K}_{2} \mathrm{O} \ldots \ldots \ldots$ & 1. 46 \\
\hline $\mathrm{Al}_{2} \mathrm{O}_{3} \ldots \ldots \ldots \ldots \ldots$ & 17. 38 & Loss........ & 2. 15 \\
\hline $\mathrm{Fe}_{2} \mathrm{O}_{3} \ldots \ldots \ldots \ldots$ & 6.57 & $\mathrm{TiO}_{2} \ldots \ldots \ldots \ldots$ & 1. 63 \\
\hline $\mathrm{FeO} \ldots \ldots \ldots \ldots \ldots$ & 3.85 & $\mathrm{PO}_{4} \ldots \ldots \ldots \ldots \ldots$ & .13 \\
\hline $\mathrm{MgO}$ & 3.42 & & Trace. \\
\hline ……. & 10. 19 & & \\
\hline $\mathrm{Na}_{2} \mathrm{O}$ & 2. 19 & & 100.5 \\
\hline
\end{tabular}

1 Pennsylvania Second Geol. Survey Rept. C3, p. 275, 1880; Rept. C6, p. 134, 1881. Analysis by F. A. Genth, jr.
This analysis gives the following norm:

Norm of diabase from Conshohocken dike.

Quartz........... 10.14 Ilmenite......... 3.04

Orthoclase......... 8.90 Magnetite....... 7.66

Albite........... 18.34 Hematite........... 1.28

Anorthite......... 33.08 Water.......... 2. 2.15

\begin{tabular}{lr|r} 
Enstatite............ & 8.60 & \\
Wollastonite....... & 6.96 & 100.49
\end{tabular}

Apatite........... .34

This diabase is a dosalane which is docalcic and presodic-in other words, the salic constituents are dominant over the femic and the lime over the alkalies. Of the alkalies soda preponderates. The rock is an augite ophitibandose.

Age.-In its freshness, mineral constitution, and microtexture the rock found in the Doe Run and Avondale region resembles the Triassic diabase. It is in line of strike with the Downingtown dike, which has been traced northeast into Triassic formations and which extends intermittently southwest as far as Maryland, crossing the Phoenixville and West Chester quadrangles and appearing in the Coatesville quadrangle as here described.

\section{STRUCTURAL GEOLOGY.}

\section{STRUCTURE OF THE PIEDMONT PLATEAU.}

The crystalline rocks of the Piedmont region comprise closely folded and faulted Paleozoic and pre-Paleozoic rocks, partly concealed by a cover of gently folded, unmetamorphosed Mesozoic shales and sandstones, which dip gently northwest and are broken by a series of normal and reverse faults with a southeast hade. In strong contrast to the simple structure of the shales and sandstones, the belt of crystalline rocks that lies southeast of the Mesozoic cover presents a succession of close unsymmetrical folds, sharply overturned toward the northwest and dislocated by thrust faults with a prevalent southeast hade. The folding appears to be isoclinal, because the limbs of the folds are compressed closely and the folds are usually overturned. They strike in a general northeasterly direction, but the axis of the major folds is usually inclined more or less gently, and this pitching of the axis shows that there has been gentle folding at right angles to the major folding. The period of stress that began in 
Archean and Paleozoic time was marked by the gradual accumulation in the earth's crust of compressive forces which sought relief in two directions, thereby producing two systems of folding-one, compressed and overturned major folds; the other, gentle and open minor folds. This difference in the intensity of folding may be due to the fact that the pressure originating along the minor axis was less than that along the major axis; or it may be due to the greater resistance of the strata along the minor axis, or to the combination of these two causes. The compressed folds lie along a northeast axis, producing a succession of overthrusts that have been gradually developed as the result of a major force working from a southeast direction. A thick limestone formation was the controlling factor in the folding of the Paleozoic sediments, and the more deeply the layer was buried the more readily it yielded to pressure.

In the sharp overthrusts of the major folds, warping of the earth's surface produced a weakness which, by concentration along the axis of overthrust, has caused a repeated sliding of the earth's crust. In the zone of combined fracture and flowage, by means of lateral pressure, combined with slight overloading, the elasticity of the material is exceeded so that the rock is fractured along the limbs of the folds, with movement along both sides of the rupture. Such faults have a gentle hade in a southeasterly direction and along them the deeply buried Archean rocks were pushed up until they overlay the younger Paleozoic sediments. The faults strike in a general northeast direction, and their linear extent is extremely variable. The faults in the Triassic beds are normal, with a hade of $75^{\circ} \mathrm{SE}$. to $90^{\circ}$ and with slight displacement.

Cleavage, fissility, and jointing are also characteristic features of the crystalline schists of the Piedmont Plateau. Jointing is caused by the yielding of the rock along shearing planes and is usually found in three directions nearly normal to one another; it is supplemented by the plane of cleavage and fissility, which is in many places almost normal to the joint planes. Fissility is a structure resulting from heat, pressure, and metamorphism, by virtue of which rocks are separated into parallel laminæ. In the gneisses and schists rearrangement and flattening of the old minerals and a production of new minerals have caused an orientation of the mineral particles with their longer axes parallel. The parallel laminæ in crystalline schists are usually coincident with the bedding planes, differing from them only where the sediments are much plicated and the plane of fissility does not follow the close crumpling of the beds.

The yielding of the rock along shearing planes which produces jointing, cleavage, and fissility is, likefolding, caused by lateral compression, owing to a tangential thrust from the direction of the Atlantic Ocean segment which continued during a long period of time and which acted most strongly in a direction at right angles to the strike of the major folds. At the same time vertical movements, bringing the beds to their present position, probably aided the work of horizontal compression, which is operative only at great depths in the zone of flowage and fracture. The two components of the force are lateral and vertical thrust. When open upright folds have passed by means of lateral thrust into closed and compressed folds, the vertical thrust tends increasingly to overturn them. The uniformity of the southeast dip of the formations shows that the major force was from that direction; the minor folding, normal to the major, resulted from suboceanic spread from the direction of the Gulf of Mexico. Tangential thrust began in pre-Paleozoic time and continued throughout the Paleozoic era, culminating at the close of the Carboniferous period. The belt of crystalline rocks which lies on the northwestern border of the Triassic cover presents the structural features described above, modified to some extent by its greater distance from the position of initial stress. In the southeastern belt an anticlinal arch brings to the surface the pre-Cambrian gneiss as the core of a great major fold. This arch, passing under the Triassic shales, is to some extent obscured by them but becomes plainly apparent along the northwestern boundary of the eastern belt of metamorphosed crystalline rocks. Farther southeast it passes into a synclinal trough of Ordovician material, of which the northwest limb forms Chester Valley and the southeast limb underlies a faulted cover of Wissahickon mica gneiss. A great anticline of pre-Cambrian gneiss follows the syncline and is succeeded by several folds which finally disappear under the 
Cretaceous sediments of the Coastal Plain, on the southeast border of the Piedmont Plateau. The structure of this pre-Cambrian anticline is much obscured by many intrusions of igneous material, and in Maryland the anticline itself is broken up by igneous material.

STRUCTURE OF THE DOE RUN AND AVONDALE REGION.

FOLDS.

In the major folds of the Doe Run and Avondale region are represented the three great anticlines and the synclines described above. In the northwest corner of the region the Baltimore gneiss forms the core of the North Chester Valley anticline, which is flanked on the southeast limb by Cambrian quartzite, succeeded by the Cambrian and Ordovician Shenandoah limestone. Farther southeast, on the South Valley Hills, the Ordovician Octoraro schist comes to the surface in a wide, shallow syncline terminated by a long thrust fault, which has brought the Wissahickon mica gneiss into direct contact with the Ordovician schist. The peculiar course of this fault plane is treated in detail on page 27 .

The rocks underlying the overthrust gneiss form a shallow synclinorium, here called the Modena-Chester Valley synclinorium. On the southeast limb of the synclinorium the underlying limestone comes to the surface in the crests of secondary anticlines, where stream erosion cutting through the overthrust cover of mica gneiss has established anticlinal valleys in the limestone.

An overturned syncline of quartzite and limestone separates the Wissahickon gneiss from the southern dome of the Baltimore gneiss, in which the rock forms a steep anticline overturned to the northwest. Southeast of this anticline, here known as the West Marlboro anticline, a synclinal wedge of limestone has been faulted upon the Baltimore gneiss along a fault plane having a very gentle southeast hade; the fault plane is split and the overthrust Wissahickon gneiss almost completely covers the syncline, leaving only a small remnant of limestone exposed. These structural features are shown in Plate III, section $\mathrm{A}-\mathrm{A}^{\prime}$, which is drawn along a line normal to the average strike of the formations. The secondary and tertiary anticlines and synclines that compose the great folds are the controlling factors in the areal distribution of the formations. The Shenandoah limestone occupies, for the most part, synclines and it represents the troughs of folds remaining after the erosion of the rest of the formation, a relation of the limestone to the adjoining formations which is illustrated in Plate III.

South of Avondale the Baltimore gneiss is closely folded into small anticlines and synclines whose character is indicated by the prevailing southeasterly dips. South of Landenberg is an area of limestone which exhibits similar structure, the southeastern limb of a syncline cut off by an overthrust from the southeast.

This structure, which is illustrated by the sections, conforms to that prevailing in the southeastern part of the Piedmont region. The only striking divergence occurs in the limestone which extends from Baker southwestward and lies north of the Westgrove area of quartzite, where there is a normal upright syncline. The primary folds may be traced along the strike to the northeast and southwest. The Cabin John and Buck Ridge anticline extends from Maryland to New Jersey and throughout its length is bounded by synclines; the northern syncline passes into the anticline of the North Valley Hills, and the southern syncline extends southwestward until it is overlain by younger deposits of the Coastal Plain or obscured by pre-Cambrian igneous rocks.

The major folds, however, do not explain the pinching out of the Baltimore gneiss, the Chickies formation, and the Shenandoah limestone parallel to the strike, while to the northeast and southwest there is a uniform exposure of the Wissahickon gneiss. The explanation of the lack of formational continuity must be sought in the minor folding, which is rather pronounced in character. The anticline of preCambrian gneiss represents a dome whose northeast and southwest flanks slope away in gentle minor synclines. A little farther northwest the same minor folding is apparent, but the axis is shorter. The northern finger-like limestone areas, from Springdell to Doe Run station and from Doe Run post office north to Buck Run, represent the crests of small minor anticlines. These anticlines pinch out toward the north, and the small minor syncline of Wissahickon mica gneiss which separates the lime- 
in both these systems is almost vertical, and the joints of the two systems, intersecting nearly at right angles, combined with the bedding plane, cut the rock into rhombohedral blocks. The third joint system, striking about N. $45^{\circ}$ E., includes strike joints which are utilized as the back faces of quarries, as in the quartzite quarry on the north side of the road leading southwestward from London Grove, where a triple system of joints shows very distinctly. The fourth joint system, which strikes N. $45^{\circ} \mathrm{W}$., is found in the Baltimore gneiss and Wissahickon mica gneiss.

\section{HISTORICAL GEOLOGY.}

\section{PIEDMONT PLATEAU.}

In order to understand the history of the Piedmont Plateau it is necessary to discuss that of the Appalachian region. A land area which has been called Appalachia existed along the present eastern border of the United States from pre-Paleozoic time, and its streams drained westward into the Appalachian Straits, an interior sea whose eastern shore was somewhere in the Piedmont Plateau and whose western shore was east of Mississippi River. The highly feldspathic shore material carried down by the Appalachian streams subsequently formed in the northern part of the Piedmont region the great expanses of Baltimore and Wissahickon gneiss, and in the southern part the thick deposits of Carolina gneiss. After the lapse of a period of time whose duration can be inferred only from the great thickness of pre-Cambrian sediments, a change in conditions set in. A gradual emergence of the land and a westward migration of the shore line took place, accompanied by igneous activity, during which large masses of granite, diorite, and pyroxenite were intruded into the preCambrian gneisses, and a process of mountain building, similar to that which produced the Sierra Nevada and the Coast Range, was begun by the uplift of the deep-seated pre-Paleozoic rocks. The ancient Appalachian streams, rejuvenated by uplift, began to cut down through the newly formed land and once more found their way by lengthened courses to a sea which had migrated toward the west and was reduced to little more than a strait.

As the conditions of heat and pressure, which had led to igneous action, resumed an equilib- rium, the widening waters of the Appalachian Straits slowly transgressed upon the shore lines of Appalachia in a period of submergence which lasted until the end of Ordovician time. Disintegrating feldspathic gneisses and igneous rocks furnished large pebbles of quartz and feldspar which were carried down by the streams and dropped along a receding shore line, forming the basal conglomerate that marks the close of the period of erosion that resulted in the preCambrian unconformity and the beginning of a long period of quiet sedimentation. North of Philadelphia, traces of this conglomerate, exposed by the upward pitch of a syncline, underlie a fine-grained white quartzite which represents the Lower Cambrian and which extends in varying thickness and amount throughout the Piedmont region. At the beginning of Cambrian time a slow subsidence of the upland was flooding the stream valleys at their mouths, forming estuaries in which was deposited shore material of coarse sand, often impure, because wave action was not sufficient to sort the material. In the northern part of the Piedmont region this sand by consolidation and metamorphism has become quartzite, or mica schist, or mica gneiss; in the south, with little or no metamorphism, it has become sandstone and shale. Its thickness is variant owing to changes in level of the strand line during deposition.

These local oscillations next gave rise to a deposit in which micaceous mud alternates with sand. Subsequent continuous erosion of the Appalachian land brought to the sea finer and finer sediments, and over the Lower Cambrian quartzite calcareous deposits were laid down in a transgressing sea, so that gradual denudation of the land, accompanied by an expanding and deepening of the sea, resulted in a thick accumulation of late Cambrian and Ordovician limestone, the Shenandoah limestone. Conditions remaining unchanged, the Cambrian period passed into the Ordovician without stratigraphic break, so that it is only by study of the changes in marine life that the periods can be separated. In later Ordovician time there was a negative displacement of the strand line and the positive element,.Appalachia, once more increased in extent, while in the west a Cambrian island was elevated above the interior sea and formed the Cincinnati arch. The streams, quickened by rejuvenation, carried 
down from the late Cambrian and Ordovician lowlands large quantities of a fine clayey mud and deposited it conformably upon the limestone, forming the Ordovician shale, which produced the Martinsburg shale of the southern Piedmont area, and probably by later metamorphism the Octoraro schist of the northern Piedmont.

The emergence that marked the close of the great period of limestone deposition continued in this region until the close of the Paleozoic era, while elsewhere a varying succession of sand and shale was laid down. At first shale succeeded limestone in all parts of the region, but when the uplift was accomplished the shale was confined to deeper-water sedimentation. Uplift continued until the Appalachian Sea was closed at the north and became a gulf.

In the southeastern Piedmont belt of Pennsylvania no sediments younger than Ordovician are found. Silurian and Devonian sediments may have been laid down and later removed by erosion, but it is likely that this area, during the deposition of the coal measures in western lagoons, was a land mass which received no further sediments until the end of the Triassic period. The Appalachian Gulf was being slowly filled, and the shore line was moving west, until, at the end of Carboniferous time, marine sedimentation in the Appalachian Straits was brought to an end.

During the post-Carboniferous period of erosion the uplifted continent was worn down by the degradation of upper Paleozoic sediments, so that if any post-Ordovician Paleozoic formations were ever present in the Piedmont Plateau they were completely removed. A slow transgression upon the eastern shore of the Appalachian continent followed the emergence of the western coast from the interior Paleozoic sea. Exactly where the Atlantic coast line stood in Mesozoic time can hardly be determined, but the evidence of the deposits of the Newark group would indicate that toward the end of the Triassic period a series of lagoons and tidal estuaries extended along the eastern border of the continent, then worn down to the level of Ordovician sediments. In the shallow, brackish water of these lagoons rivers were depositing the mud and sand from the eroded Paleozoic rocks which subsequently formed the ripple-marked red shales and sand- stones of the Newark group. Volcanic activity accompanied the sedimentation, resulting in flows of basic lava and in the intrusion of sills and dikes of diabase which extend with various interruptions from the great Palisades of New York to isolated dikes in Maryland. With the emergence of the Newark sediments the last sedimentation distinctive of the Piedmont Plateau came to a close. The history of all succeeding deposits may be read in the adjoining Coastal Plain province.

\section{DOE RUN AND AVONDALE REGION.}

The formations of the Doe Run and Avondale region present an epitome of the geologic history of the Piedmont Plateau from early pre-Cambrian through Ordovician time. In order to understand the somewhat irregular sedimentation of this area the conditions of deposition must be clearly borne in mind. It will be remembered that the Appalachian continent, worn by erosion to a region of low relief, lay to the east of the present Piedmont district, and the interior sea, which had widened in the south probably as far east as the present Atlantic shore and had migrated in the west across the great Appalachian Valley to Missouri and Wisconsin, was rapidly narrowing in its northern part to little more than a strait. The sediments which form the Wissahickon mica gneiss were being laid down in a thick deposit along the shore line of Appalachia. That the southern portion of the Doe Run and Avondale region remained, in part at least, a land mass until the beginning of Cambrian time is a conclusion suggested by the absence of the Wissahickon mica gneiss between the Baltimore gneiss and the Cambrian quartzite in the Woodville-Chatham anticline, and by the presence on the flanks of the igneous core of a sedimentary transition facies of the Baltimore gneiss. Pumpelly ${ }^{1}$ has described a gneiss from Hoosac Mountain, Vt., which presents the same anomalous feature-that of a transitional form apparently in direct continuity with two formations otherwise separated by a great time break and an erosional unconformity. $\mathrm{He}$ explains the gneiss of Hoosac Mountain as a local consolidation of

1 Pumpelly, Raphael, The relation of secular rock disintegration to certain transitional crystalline schịts: Geol. Soc. America Bull., vol. 2, pp. 209-224, 1890. 
decayed rock material; according to him the consolidations favorable for deep rock disintegration are "a land surface exposed during a long period to the influence of a moist climate and protected by vegetation."

Toward the end of pre-Cambrian time the land surface of the Avondale district had reached an advanced stage of disintegration similar to that described by Pumpelly as consisting of three zones. On the surface was a layer of kaolinized material, forming a clay; between the semikaolinized material and the fresh rock was a zone in which the process of disintegration had advanced only far enough to weaken mineral cohesion by alteration of the micaceous or hornblendic layers. A residual soil produced under such conditions would remain in place, forming a deep zone that would grade insensibly into a layer in which disintegration had not been accompanied by decay.

That compressive stress was already acting upon the Baltimore gneiss of the Pennsylvania Piedmont is shown by the intrusions of gabbroitic magma now found in the pre-Cambrian gneiss; at the same time folding and metamorphism were taking place, thereby giving a gneissic character and simulated conformity to both igneous and sedimentary formations. During this period of stress the semidisintegrated material in the zone of weakened cohesion, overlying the true gneiss, yielded readily to pressure and was consolidated, assuming the gneissic structure of the parent rock.

The transgression which ushered in the Cambrian period was contemporaneous with the development of the thrust force which metamorphosed pre-Cambrian rocks into gneisses. The residual clay soil, washed away by the rapidly advancing waves, was deposited in deep water far from the shore; the coarse semikaolinized material, an easy prey to erosion, was carried to the sea and deposited near the shore, subsequently forming the conglomerate that marks the base of the Cambrian; the removal of these two upper zones exposed the lower beds of secularly disintegrated rock that had been consolidated in place; and by the erosion of this transitional gneiss material was furnished for the formation that was later consolidated and metamorphosed into the Lower Cambrian mica gneiss of the Chickies formation.
During later Cambrian and Ordovician time the sedimentation of the Doe Run and Avondale region was quiet and continuous, uninterrupted by any marked disturbance. Streams working in the pre-Cambrian gneisses of the northern and southern areas were cutting out a fine quartzose sand which was deposited at river mouths in deepening estuaries.

Submergence continued without local uplift, so far as the evidence shows, and deepening water in Upper Cambrian time received the wide limestone deposit which continued into the Ordovician period and probably extended over the whole surface of the Doe Run and Avondale region. A slight negative movement of the strand line ensued, and a load of fine mud was poured into the clear waters of streams that had been carrying lime in solution. The first result of the change in stream content was the deposition of a calcareous shale upon the surface of the limestone. On further uplift erosion washed down from the lowlands large quantities of finely divided clayey material, which was subsequently consolidated to a shale and metamorphosed to the Octoraro schist. Deposition of Silurian sediments upon the Ordovician shale seems probable, but all positive evidence of such sedimentation has been removed by subsequent erosion. In the southern part of Pennsylvania adjacent to the Piedmont Plateau, as estimated by Stose, ${ }^{1}$ the total thickness of the Paleozoic sediments is 20,000 feet, and about 4,000 feet of this thickness represents post-Martinsburg sedimentation; it is therefore probable that in the Doe Run and Avondale region a light load of sediments may have covered the Ordovician shales.

In the pre-Cambrian sea southeast of the Doe Run and Avondale region the Wissahickon mica gneiss had been deposited in the form of an arkosic argillite, which during the late preCambrian period of diastrophism was consolidated and metamorphosed. Before the beginning of the Paleozoic era the Wissahickon gneiss suffered erosion in the pre-Cambrian mountains of Appalachia, and when the western part of Appalachia was buried beneath Paleozoic sediments the gneiss was brought into the zone of anamorphism and was subjected to the

1 Stose, G. W., The sedimentary rocks of South Mountain, Pa.: Jour. Geology, vol. 14, pp. 201-220, 1906: U. S. Geol. Survey Geol. Atlas, Mercersburg-Chambersburg folio (No. 170), 1909. 
compressive forces that operated throughout the Paleozoic era. Through the whole of early Paleozoic time a slowly accumulating earth stress was making itself felt in deeply buried sediments. The resistant power of the Shenandoah limestone, combined with its extent, made it a competent stratum in the process of folding. According to C. W. Hayes ${ }^{1}$ the requisites for great overthrust movements are a light load upon a competent stratum. The Shenandoah limestone at first offered the requisite resistance to the strong thrust force, and later, after it had been folded into gentle open folds, it gave way to the accumulating stress which thrust the Wissahickon gneiss, originally deposited on the western shore of Appalachia, far over the surface of the folded limestone.

From a study of the structure in the Doe Run and Avondale region it seems probable that there were two periods of folding during Paleozoic time. It is an accepted fact that the Appalachian Mountains are a pre-Permian range which is connected, by way of the mountains of Newfoundland and Nova Scotia, with the pre-Permian mountains of Europe-the Armorican-Variscan ranges. In the Piedmont Plateau the effects of the pre-Permian diastrophism which formed these mountains are seen in the folding and faulting of the Paleozoic formations. In Scandinavia, Scotland, and Ireland the Armorican Mountains follow the line of an older range-the pre-Devonian Caledonian Mountains. The pre-Cambrian platform in the Caledonides, according to Peach and Horne, " "has been driven forward until the Archean rocks have been carried over the truncated edges of the Silurian strata." In the Scottish Highlands the presence of Lower Devonian strata, unaffected by this period of thrusting and faulting, makes evident the age of the movement. In the Piedmont Plateau there is a similar series of pre-Cambrian and Cambrian and Ordovician rocks. Here also an overthrust has brought pre-Cambrian gneiss over Paleozoic sediments, but in the Doe Run and Avondale region erosion has removed the Silurian and post-Silurian rocks, so that proof of the age of the thrusting can not be found in the presence of undisturbed material.

${ }^{1}$ Hayes, C. W., The overthrust faults of the southern Appalachians: Geol. Soc. America Bull., vol. 2, pp. 141-154, 1891.

2 Peach, B. N., and Horne, J., Nature, vol. 31, p. 33, November, 1884; see also London Geol. Soc. Quart. Jour., vol, 44, p. 378, 1888.
In Brazil and in northwestern Europe there are pre-Devonian mountains whose formation was due to the same cause-tangential compression derived from suboceanic spread. It is probable that this compression affected Appalachia, the great positive element of the eastern Atlantic region, as well as the northern and southern Atlantic regions, though the resulting diastrophism may not have been exactly contemporaneous. Schuchert considers the Taconic revolution (the pre-Silurian period of folding and thrusting in eastern America) the most marked disturbance of the era except the Appalachian revolution; it may be that the time of thrusting in Appalachia was preSilurian, instead of pre-Devonian, corresponding to the age of the Caledonides in northern Africa. It is possible that the thrusting was a gradual movement which kept pace with the deposition that probably occurred in eastern Pennsylvania during Devonian time. By the end of the Carboniferous period a reaccumulated earth stress once more found relief in a period of folding by which the already overthrust gneiss was folded along with the underlying rocks.

To these Paleozoic earth stresses, therefore, the rocks of the Doe Run and Avondale region owe their present complicated and overturned structure, which was already established before erosion had carried its work so far as to expose to view the Ordovician schist. Upon the degraded surface of this schist later Tertiary and Quaternary deposits have been laid down and again completely removed by erosion.

The fact that these deposits once extended over the whole region is proved by the character of the underlying drainage. The courses of the larger streams show them to be out of adjustment to the underlying formations, and such a discordance can be explained only as a superimposition of drainage inherited from a cover of material that was sufficiently deep to establish the streams firmly in their present. courses.

\section{CONCLUSION.}

Nowhere in the Piedmont Plateau does the Wissahickon mica gneiss have easily interpreted relations to other formations. Near Philadelphia it is in contact with the Baltimore gneiss, an ancient pre-Cambrian formation which served as a floor for sediments of 
later age, or it is adjacent to younger sedimentary material from which it is separated by faulting. Elsewhere in this paper it has been stated that the Wissahickon mica gneiss and the Octoraro schist are in contact in the Doe Run region and the immediately adjoining area. The question of their age and of their structural relations has been a moot point, not only because of the difficulty in determining the age of the Wissahickon gneiss but also on account of the ambiguous structural relations existing between the mica gneiss and the Ordovician limestone. In the Coatesville quadrangle small outcrops of limestone occurring within the mica gneiss exhibit a relation which has a significant bearing upon the problem of the age of the mica gneiss.

The age of the limestone must be first determined, but absence of fossils, metamorphism, and complicated structural relations make this determination difficult. The limestone may belong to the pre-Cambrian and be the equivalent of the Franklin limestone toward the east, or it may be the representative of the Cambrian and Ordovician Shenandoah limestone. The limestone of the Doe Run and Avondale region is lithologically dissimilar to the Franklin limestone, and it is not associated with graphitic gneiss, which usually accompanies the Franklin limestone. On the other hand, the limestone of the Doe Run and Avondale region bears a complete lithologic resemblance to the Shenandoah limestone of Chester Valley. It occurs in a conformable series with a quartzite which has been correlated with the Chickies quartzite of the North Valley Hills. Moreover, the southern limestone areas of the Doe Run and Avondale region are in the direct line of strike with the Shenandoah limestone of Cream Valley, west of Conshohocken. For these reasons the limestone of the region under discussion is correlated with the Shenandoah.

The readily determined relation between the Ordovician mica schist and the great belt of Shenandoah limestone, which has been proved by fossil content to be of Cambrian and Ordovician age, establishes the age of the mica schist as Ordovician. ${ }^{1}$ The conformable contact of the schist upon the limestone is shown by the

\footnotetext{
1 Merrill, F. J. H., U. S. Geol. Survey Geol. Atlas, New York folio (No. 83), p. 4, 1902. Bascom, Florence, idem, Philadelphia folio (No. 162), p. 5, 1909 .
}

lithologic gradation of the limestone through a calcareous mica schist into the overlying formation, as seen in Chester Valley near Coatesville, and also by the constant presence of a single bed of geodiferous, siliceous material along the line of contact, ${ }^{2}$ thereby proving that the contact can not be a fault line.

The fact that no fossils have been found in the Wissahickon mica gneiss makes it necessary in determining its age to rely altogether upon its stratigraphic relations to other formations. In dealing with the relations of the mica gneiss to the Ordovician Octoraro schist it must be decided whether the gneiss is of the same age as the schist and grades into it, or whether the gneiss is of different age from the schist and is separated from it by a thrust fault. The evidence in the Doe Run and Avondale region seems to indicate a difference in age notwithstanding a marked resemblance between the two formations. A certain resemblance between the gneiss and the schist, both in the hand specimen and in the field, has caused considerable difficulty in distinguishing them and has given rise to the supposition that the mica gneiss is probably of Ordovician age. On close examination, however, it becomes evident that the apparent gradation of gneiss into schist across the line of strike is not actual. A detailed study of the region has established both lithologic and structural differences, shown by the following facts which have been used as a lithologic basis of separation between the two rocks:

1. The mica gneiss always contains feldspar, usually in large amounts; the mica schist is almost free from feldspar.

2. The gneiss shows close crumpling and many fine plications; the schist is straight bedded.

3. The gneiss is garnetiferous; the schist is not.

4. The gneiss shows evidence, in coarser crystallinity, of having undergone greater metamorphism than the schist; and the change in metamorphism is too abrupt and well marked to be explained as the result of gradual eastward increase of the metamorphic action that prevailed throughout the Piedmont Plateau.

5. The chemical analysis of the gneiss shows the composition of an arkose which has under- 
gone injection and impregnation, while the schist has the composition of an argillite.

6. The dip of the gneiss is gentle, about $30^{\circ}$; that of the schist averages about $60^{\circ}$.

7. There are four well-marked joint systems in the gneiss, whereas the schist possesses only three joint systems.

The coarser crystallinity of the gneiss and the development of deep-seated metamorphic minerals not found in the schist, together with the presence in the gneiss of one joint system and many plications that are absent in the Ordovician material, are evidences that the mica gneiss has been subjected to the influence of one more period of diastrophism than the schist and is therefore much older than Ordovician.

As the Wissahickon gneiss must be older than Ordovician, let us examine the stratigraphic column in the Doe Run and Avondale region in order to decide at what horizon the gneiss is most likely to belong. It can not be considered younger than the limestone-that is, underlying the schist and overlying the limestone-because of the conformity which has been established between the limestone and the mica schist. That the mica gneiss can not be included within the Shenandoah limestone is shown by the prevalent calcareous nature of the Shenandoah deposits seen in the Great Valley and in the Piedmont region of eastern Pennsylvania. The generally conceded conformity between the Lower Cambrian deposits and the Shenandoah limestone excludes the gneiss from a position between the limestone and the quartzite and proves that the Wissahickon is as old as or older than the Chickies formation.

It therefore remains to be considered whether there is sufficient evidence to warrant the inclusion of the Wissahickon gneiss in the Paleozoic succession by placing it within the Lower Cambrian. The character of the Wissahickon and the absence of similar rock within the Lower Cambrian of other regions make it seem unlikely that a great thickness of arkosic material may be included within Lower Cambrian rocks, which elsewhere in the Appalachian province indicate a persistently arenaceous sedimentation.

It has been shown that the mica gneiss can not be younger than the Shenandoah limestone, that is, of Ordovician age-and also that it can not be of Cambrian age; hence by exclusion from the Paleozoic succession the mica gneiss becomes pre-Cambrian. Positive evidence of this age is found in the relation which the igneous intrusives bear to the Wissahickon formation. The mica gneiss is penetrated by granite, gabbro, and ultrabasic intrusive rocks whose horizon is bounded by pre-Cambrian rocks. These intrusive rocks are found in the Baltimore gneiss and the Wissahickon mica gneiss, but are not found to a significant extent in Paleozoic rocks of known or questionable age. The Paleozoic rocks are therefore separated from the Wissahickon mica gneiss by an unconformity which determines the pre-Cambrian age of the mica gneiss.

A further confirmation of the pre-Cambrian age of the Wissahickon gneiss is the fact that the formation can be traced westward from the Doe Run and Avondale region through southeastern Pennsylvania into Maryland and thence into the District of Columbia and Virginia. The formation in the neighborhood of Washington which is lithologically similar to the mica gneiss of Doe Run and Avondale has been described by Keith ${ }^{1}$ as the Carolina gneiss and determined as pre-Cambrian.

The Shenandoah limestone on the south side of the Cabin John and Buck Ridge anticline has been folded into a syncline which is made up of many secondary folds. The Wissahickon mica gneiss occupies the center of many of these synclines, most of which are overturned toward the northwest, giving the strata isoclinal dips. In order to explain the presence of a pre-Cambrian gneiss in immediate contact with the Cambrian and Ordovician limestone and the Ordovician schist it is necessary to assume the existence of a deep overthrust fault, the origin and nature of which have been described and which has brought the older formation along a gentle hade to lie upon the younger Paleozoic rocks. The resulting discordance has been obscured by a subsequent diastrophic movement that has folded and faulted the thrust plane as if it were a plane of stratification.

In the neighborhood of Philadelphia Miss Bascom ${ }^{2}$ has established two presumably continuous fault lines along Huntingdon and Cream

1 Keith, Arthur, U. S. Geol. Survey Geol. Atlas, Washington folio (No. 70), p. 2, 1901.

2 Bascom, Florence, U. S. Geol. Survey Geol. Atlas, Philadelphia folio (No. 163), p. 16, 1909. 
valleys. The Cream Valley fault has brought up the Buck Ridge anticline of pre-Cambrian gneiss until it overlies the syncline in the Ordovician schist. The westward continuation of this fault lies along the contact of the Wissahickon gneiss and Octoraro schist and extends directly into the Doe Run region. The change in dip between the schist and the gneiss is structural confirmation of the existence of a fault which is in complete accord, not only with the prevalent type of Piedmont structure as determined in the eastern Atlantic States, but also with the structure of regions similar to the Piedmont of the United Statesfor example, northern Scotland and Scandi- vician metamorphism. navia, where overthrusting of like character and magnitude has been worked out.

Therefore, as the existing evidence seems to indicate a pre-Cambrian age for the Wissahickon mica gneiss, and as the structure necessary to explain the relations of the gneiss to the Paleozoic sediments is in keeping not only with the intrinsic structural evidence of the formations but also with the structure of regions similar to the Piedmont of Pennsylvania, it seems fair to conclude that the Wissahickon mica gneiss is separated from the Shenandoah limestone and the Octoraro schist by a thrust fault which has been obscured by post-Ordo- 